\title{
MEZI SKLEM A KERAMIKOU. STŘEDOVĚKÁ JÍMKA 962 Z CHRUDIMI - HRADEBNÍ ULICE
}

\author{
JAN FROLÍK - ROMANA KOZÁKOVÁ - JAN MUSIL - KATEŘINA VAĎUROVÁ
}

\begin{abstract}
Abstrakt: Odpadní jímky jsou významným pramenem pro poznáni životni úrovně a řemesla v připadě, že o majiteli parcely, na niž se nacházejí, nejsou dochovány písemné zprávy. Výzkum zároveň ukazuje, že jejich zaplñováni může být opakované, střidané s úplným či částečným vybiráním v delším časovém období. Přikladem je i jimka 962 z Chrudimi, v jejiž výplni byly rozlišeny dva časové horizonty, jimž odpovidá složení souboru keramiky a skla. Nálezový soubor patři z hlediska středověké Chrudimi k průměrným, jen s ojedinělými doklady luxusu a nenaznačuje řemeslo uživatele.
\end{abstract}

Klíčová slova: město - odpadní jímka - keramika - sklo-zacházení s odpadem.

\section{Between glass and pottery. Medieval refuse pit no. 962 from Chrudim, Hradební Street}

\begin{abstract}
Refuse pits are important sources for the study of living standards and crafts in cases when there exist no written records about the owners of the plots where they are located. What is more, research has shown that they were filled repeatedly, in combination with their full or partial emptying over long periods of time. One example is refuse pit no. 962 from Chrudim, in the fill of which two chronological horizons were identified, corresponding to the composition of a pottery and glass series. In the context of medieval Chrudim, the series is an average one, with only sporadic evidence of luxury goods, and does not indicate the owner's craft.
\end{abstract}

Key words: town - refuse pit-pottery-glass - waste disposal.

\section{1 Úvod. Okolnosti výzkumu}

V roce 2006 proběhl v historickém jádru východočeského města Chrudimi dosud největší záchranný archeologický výzkum, a to $\mathrm{v}$ Hradební ulici na parcelách zaniklých domů čp. 14/I a 15/I a na zahradě původně náležející k čp. 10/I (obr. 1 - Frolík-Musil 2007; 2010). Záchranným archeologickým výzkumem bylo získáno významné svědectví o využití zkoumané plochy v pravěku (kultura slezskoplatěnická - Novák 2010) a pak kontinuálně od 9. století, kdy zde vzniklo hradiště, vyvíjející se ve významný článek přemyslovské správní soustavy v 11. až 13. století ve východních Čechách. Před rokem 1276 bylo na jeho místě lokováno vrcholně středověké město (Frolík-Sigl 1998). Na zkoumané ploše se to projevilo vyměřením tří městišt' přiléhajících na východní straně k ulici (dnes Hradební ulice). Domovní zástavba byla detailně zkoumána v severní části plochy, kde byl nalezen zaniklý dům dokládající, že zahrada novodobě náležející k domu čp. 10/I tvořila původně samostatné městiště. Počátky domu sahají do druhé poloviny 13. století, jeho zánik je datován do období třicetileté války. Dům poté již nebyl obnoven a místo bylo přičleněno k domu čp. 10/I (Frolík-Musil 2014).

Výraznou součástí nálezového fondu jsou odpadní jímky a jámy (obr. 1). Jako jímky (celkem deset) označujeme v půdorysu pravidelné jámy (kruhové či pravoúhlé) obvykle s dřevěnou úpravou stěn nebo obezděním z kamenů na sucho. Odpadní jámy (celkem čtyři) úpravu stěn postrádají. Chronologicky zahrnují období od přelomu 13. a 14. století až do století osmnáctého. Zdá se, že po třicetileté válce byly hloubeny již jen odpadní jámy.

Nejvíce odpadních jímek spojujeme s parcelou domu čp. 14/I (celkem sedm jímek - jímky 927, 928A, 928B, 932, 938, 951 a 954). Jedna jímka náleží k zaniklému domu (jímka 943) a jedna k domu čp. 10/I (jímka 973). Jímky pokrývají období od přelomu 13. a 14. století (jímka 928B) až do století osmnáctého (jímky 932 a 938). Pouze jedna jímka také souvisí s domem čp. 15/I (jímka 962). Původně byl jako jímka označen také objekt 952, ale jeho výplň nemá charakter odpadních vrstev a pravděpodobně se jedná o pec. 


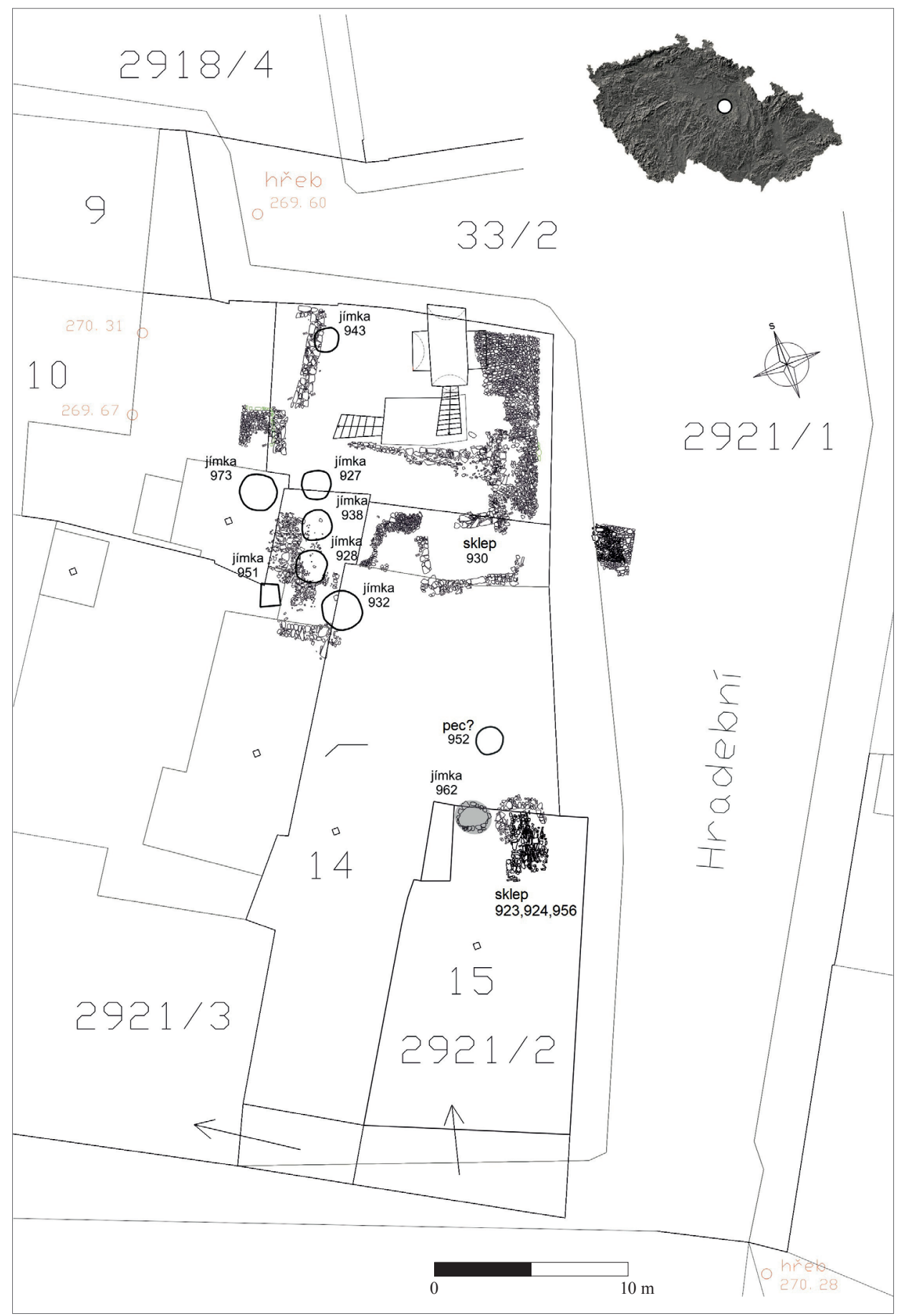

Obr. 1. Chrudim, Hradební ulice. Celkový plán výzkumu v roce 2006 s vyznačením polohy jímky 962 (zvýrazněna šedě). Podklad GEO.CZ, upravili J. Frolík a J. Musil.

Abb. 1. Chrudim, Hradební-Straße. Gesamtplan der Grabung von 2006 mit Kennzeichnung der Lage von Abwassergrube 962 (grau hervorgehoben). Unterlage GEO.CZ, bearbeitet von J. Frolík und J. Musil. 
Všechny jímky i odpadní jámy byly zkoumány po přirozených vrstvách, což dovolilo sledovat detailně způsob jejich zaplňování. V jímkách se původně nacházel měkký nezkonsolidovaný zásyp, který se postupně sesedal, takže vytvářel charakteristické zvrstvení s uloženinami, jejichž okraje vybíhaly nahoru podél stěn jímky (řez uloženinou se podobá písmenu U). Měkký zásyp také bezesporu umožňoval, alespoň zpočátku, propadání těžších předmětů do starších uloženin. Postupné sesedání mohlo činit až dva metry. Projevovalo se velmi dlouho po vyřazení jímky z provozu. Obvykle tvořilo horní část výplně jímek mnohem mladší souvrství odlišného charakteru, často s nálezy 18. až 19. století (např. jímka 938). U některých jímek se podařilo doložit, že nad nimi zřejmě stála lehčí dřevěná stavba (prevét?, např. jímka 932 - Frolík-Kozáková-Musil 2018). Výplně středověkých jímek byly podrobeny př́rodovědným analýzám (Baloghová 2010; Bartošová 2009; Bartošová a kol. 2011; Kodýdková 2009). V př́ípadě níže popisované jímky 962 byly publikovány výsledky paleoparazitologie, přičemž bylo doloženo promoření obyvatel domu čp. 15/I škrkavkou psí/kočičí (Toxocara canis/cati), škrkavkou dětskou (Ascaris lumbricoides) a tenkohlavcem lidským (Trichuris trichuria - Bartošová a kol. 2011, Fig. 10).

\section{Písemné prameny}

Konfrontace s dochovanými písemnými prameny přináší určité problémy. Zkoumané parcely a s nimi celý blok domů se nacházely ve čtvrti, která byla v soudobých písemných pramenech nazývána Klášterská, a to podle blízkého dominikánského kláštera situovaného v severovýchodním nároží městského areálu. Klášter zanikl za husitských válek, na jeho místě existovalo městské vězení, pravděpodobně využívající zbytků klášterních budov. Zánik kláštera následně znamenal změnu názvu čtvrti, dále byla označována jako Bohatá. Pro Bohatou čtvrt' bohužel nejstarší písemné prameny představují především městské knihy z 16. až 17. století, čímž se míjejí s chronologickým zařazením většiny archeologických situací. Domovní blok tvořilo v novověku sedm nemovitostí, připočteme-li zaniklý, archeologickým výzkumem objevený nárožní dům, pak osm. V době výzkumu stály pouze tři domy, a to samostatná čp. 9/I a 10/I. Původní čp. 11/I až 13/I byla sloučena v jeden celek.

Nejstarší zmínku o nárožním domě čp. 15/I, který zaplnil převážnou část plošně omezené rohové parcely, nacházíme k roku 1601, kdy ho proslulý chrudimský maliř Matouš Radouš prodal šenkýři Martinovi. Jeho osudy můžeme sledovat až do roku 1637. Následně byl zničen, protože v roce 1711 město prodává „misto pusté“ k nové výstavbě. Dům, který zde stál až do 90 . let minulého století, byl postaven v 19. století. Podle archeologického výzkumu mu předcházela starší podsklepená stavba, vzniklá po roce 1711. Stopy starší zástavby v jejím okolí zjištěny nebyly, a proto byla pravděpodobně plošně menší než zbořený dům 15/I.

Písemné zprávy, byt' poměrně pozdní, však jednoznačně dokládají, jak velkým zásahem do městského života byla $\mathrm{v}$ Chrudimi třicetiletá válka. Z osmi domů sledovaného bloku zůstaly stát zřejmě jenom dva (čp. 11/I a 13/I). Zpustlá městiště prodávala obec jako svědectví toho, že původní majitelé bud' zahynuli, nebo nuceně emigrovali (čp. 11/I). Jeden z domů nebyl nikdy obnoven a jeho pozemek byl přičleněn k čp. 10/I. Obnova nemovitostí se protáhla na několik desetiletí (jako poslední dům čp. 15/I po roce 1711). Ve zkoumaných jímkách s tímto a mladším obdobím souvisí pouze ta část výplně, která vyrovnávala depresi po starších slehlých vrstvách. Obsah odpadních jímek je tak převážně jedinou možností, jak charakterizovat majitele parcely v období před rokem 1600, protože pro tuto část Chrudimi schází starší písemné prameny (přehled písemných zpráv podle Florián s. d.).

\section{Terénní situace}

Odpadní jímka 962 byla situována osamoceně v severozápadním rohu čtverce G6. Zahloubena byla do starší sídlištní vrstvy (uloženina G6/119) a výkop dosáhl až na podloží (G6/145). Jímka byla vyzděna z lomové opuky na hlínu (šedohnědý písčitý jíl). Půdorysně se jednalo o mírný ovál 
(vnější průměr $1,7 \times 1,8 \mathrm{~m}$, vnitřní $1,2 \times 0,95 \mathrm{~m}$ ), hloubka činila 2,6 m. Jímka byla vyzděna ve stejném průměru na celou výšku, v horní partii se však mírně lahvovitě zužovala (v dokumentovaném profilu z 1,3 na $1,0 \mathrm{~m})$. Výplň sestávala celkem z 20 různě mocných uloženin (G6/125 až G6/144), které můžeme rozdělit na tři části s podobnými vlastnostmi (obr. 2). Spodní část v rozsahu uloženin G6/135 až G6/144 se vyznačuje vyšším zastoupením úlomků dřeva a uhlíků (35 až 45 \% - uloženiny G6/136 a G6/142). Ve dvou př́ípadech byla organická složka popsána jako rašelina, bezesporu se však jednalo o zcela rozložené dřevo, eventuálně o jiné další organické hmoty (uloženiny G6/138 a G6/140). Dřevo však bylo dochováno převážně v podobě drobných

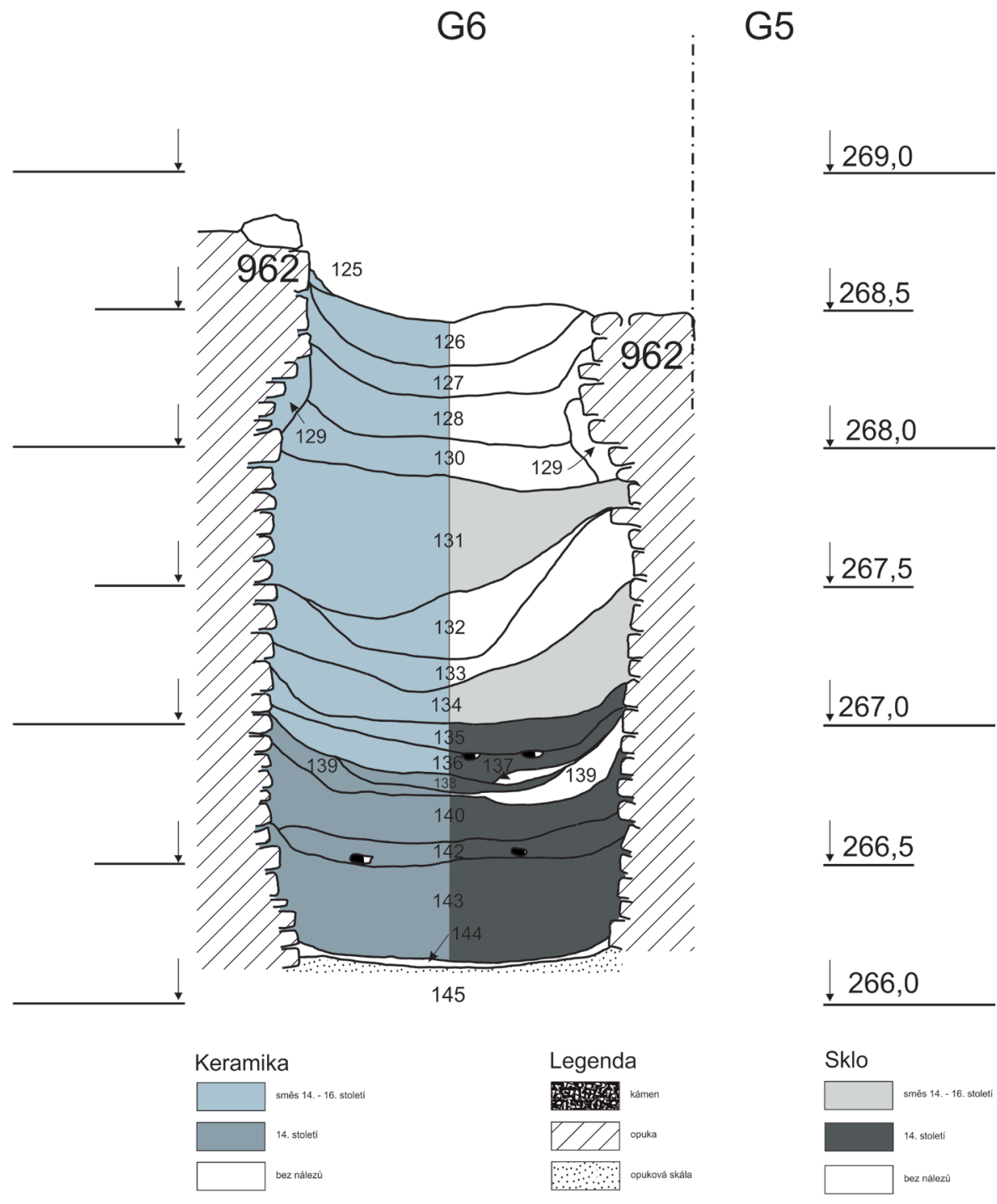

Obr. 2. Chrudim, Hradební ulice. Jímka 962. Jižní řez. Vlevo horizonty podle keramiky, vpravo podle skla. Vyhotovil J. Musil. Abb. 2. Chrudim, Hradební-Straße. Abwassergrube 962. Südlicher Schnitt. Links die Horizonte gemäß der Keramik, rechts gemäß Glas. Erstellt von J. Musil. 
zlomků, z nichž nebylo možné určit původní funkci a ani je využít pro dendrochronologické datování. Přítomnost dřevěných konstrukcí v blízkém okolí dokládá prrítomnost malých fragmentů mazanice (uloženina G6/139 - až 15 \%). Celková mocnost této části zvrstvení činí 1,05 m. Výše se charakter uloženin mění, stoupá přítomnost opukových kamenů (20-30 \%; uloženiny G6/134, G6/133, G6/130, G6/128 a G6/126), které jsou dokladem zděných konstrukcí v okolí (obr. 3). Další změnu od úrovně uloženiny G6/130 signalizuje př́tomnost fragmentů cihel (G6/130 a G6/125). Řez jímkou také dokládá, že se původní výpln̆ v mladším období, nejspíše po úplném zaplnění, sesedala. Dokládají to dutiny u stěn v místech zúžení jímky v horní části druhotně vyplněné uloženinou G6/129. Celková mocnost horní části souvrství činí $0,95 \mathrm{~m}$ u vrstev jen s opukovými kameny (tj. G6/134 až G6/131) a 0,7 m u vrstev, v nichž se již objevují fragmenty cihel (G6/130 až G6/125). Velikost dutin u stěn ukazuje na sesednutí zásypu v důsledku jeho vysychání o 0,2 až 0,3 m. Po zániku byla celá jímka převrstvena uloženinou G6/124, která se zčásti druhotně prosedla do povrchu jímky.

Výplň jímky dokládá na základě změněného charakteru uloženin nejméně dvě etapy jejího zaplňování. Pozůstatkem starší z nich jsou vrstvy až do úrovně uloženiny G6/135, výše uložené souvisí s mladší etapou využívání jímky, a to bezesporu po částečném vybrání starší výplně. Eventuální nevelký rozdíl v charakteru vrstev od uloženiny G6/130 a možný doklad třetí etapy může doložit pouze rozbor nálezů. Pokud by se potvrdil, je možné, že tyto uloženiny vznikly v rámci vyrovnávání prolákliny po sesedající se výplni jímky. Podobný proces je doložen také u dalších jímek v Hradební ulici (např. jímka 938).

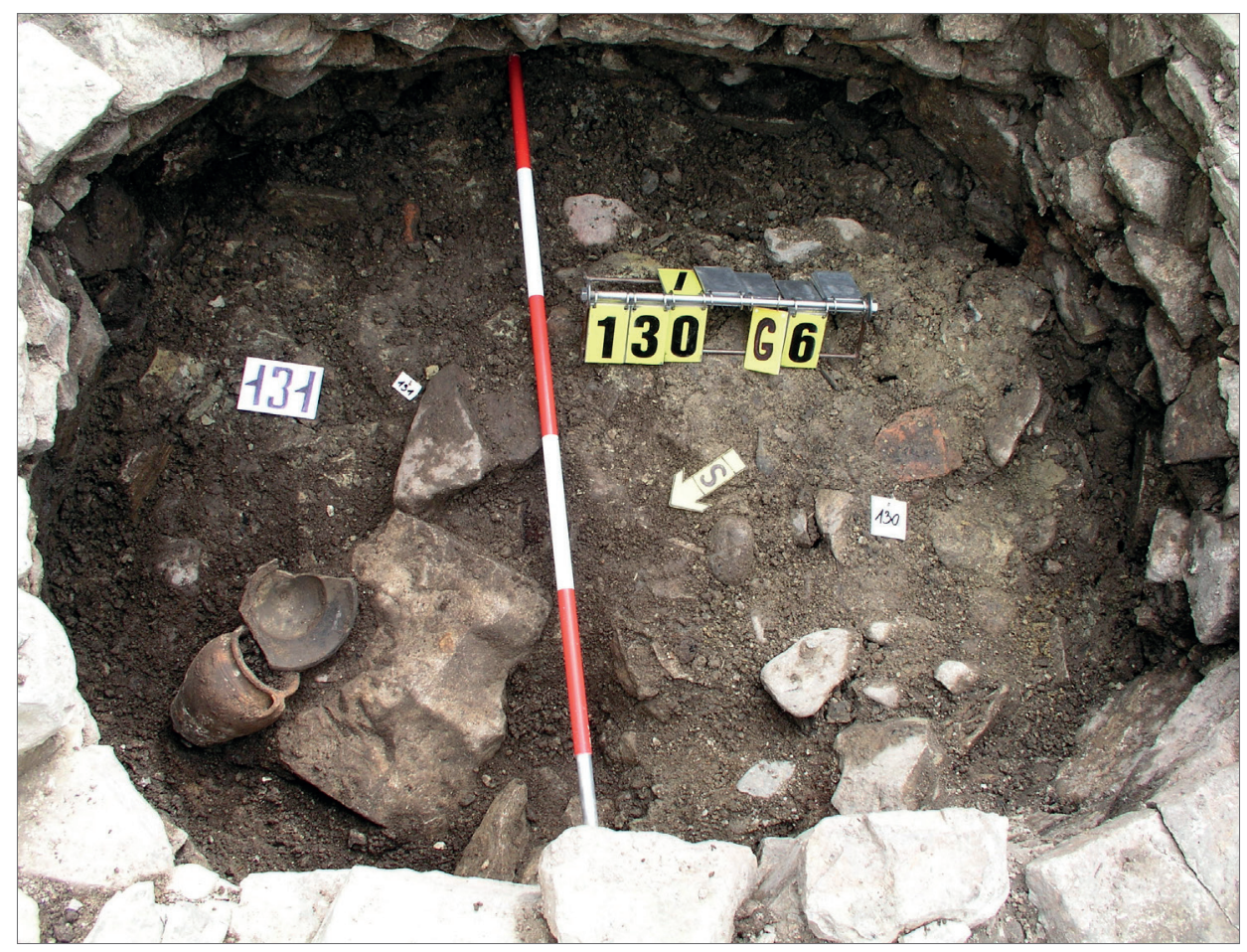

Obr. 3. Chrudim, Hradební ulice. Jímka 962. Vlevo terénní situace v úrovní uloženiny G6/131, vpravo G6/130. Trasírka je umístěna v místě řezu jímkou. Foto P. Kaplan.

Abb. 3. Chrudim, Hradební-Straße. Abwassergrube 962. Links Geländesituation auf Höhe von Ablagerung G6/131, rechts G6/130. Die Trassierstange wurde an die Stelle des Schnittes durch die Grube gelegt. Foto P. Kaplan. 


\section{Nálezy}

\subsection{Keramika}

Celkem bylo vyhodnoceno 1273 zlomků keramiky, 56 celých nádob a jejich torz o celkové hmotnosti 32259 g. Keramiku lze na základě makroskopicky postižitelných vlastností1 rozčlenit do 32 základních keramických technologických tříd (dále KT), které mají rovněž chronologický význam (Frolík-Musil-Sigl s. d.). Typologie okrajů byla převzata podle třídění M. Zápotockého (1978, obr. 5), pro radélkovou výzdobu bylo užito typáře J. Musila (2009, 50). Celkem 37 zlomků (KT 001 a KT 002) o celkové hmotnosti 289 g nebylo možné blíže zařadit vzhledem ke stavu jejich dochování.

Nejstarší studované zlomky keramiky náleží do raně středověkého období (KT 201-204, 207). Celkem se jedná o 39 zlomků o hmotnosti 373 g. Keramika náležící technologickým třídám KT 201-204 a 207 se vyskytuje jak ve svrchních partiích jímky (v rámci uloženin G6/125-G6/128, G6/131, G6/133-G6/135), tak i při bázi jímky (uloženina G6/143). V našem souboru představují intruzi a nebude jim věnována bližší pozornost (základní informace o raně středověké keramice na Chrudimsku srov. Frolík-Sig1 1995).

Na přelom 13. a 14. století můžeme klást výskyt částečně ještě obtáčeného zboží tmavě hnědých a hnědošedých tónů (KT 210, 7 ks, 131 g). Rozpoznány byly pouze zlomky kuchyňské keramiky pocházející z hrncovitých nádob. Z hlediska okrajové profilace registrujeme okraje vytažené a nepravá okruží s vnitřním prožlabením (typ H315 - 1×; H352 - 1×). Pouze jeden zlomek nese výzdobu v podobě oběžné šroubovice. Mimo Chrudim známe toto zboží např́íklad z nedalekých Dvakačovic (KT Dvakačovice 25 - Frolík-Musil-Sigl s. d.), z areálu podlažického kláštera (KT Podlažice 21 - tamtéž), z hradu Košumberka (KT Košumberk 210 - tamtéž), z Hrochova Týnce (KT Hrochův Týnec 5 - Frolík-Stránská-Švédová 2018), Lažan (KT Lažany 2 - Frolík 2019, 77-112) či ze Lhoty u Skutče (KT Lhota u Skutče 1 - Musil 2017).

Importem z německého prostředí je vysoce kvalitní šedá kovově lesklá keramika s bílým lomem (KT 235, 7 ks, $447 \mathrm{~g}$ ). V popisovaném souboru je tato bezesporu luxusní keramika zastoupena torzem grapenu (obr. 6:4) a několika zlomky pocházejícími pravděpodobně ze džbánu zdobeného radélkem a vývalkovou šroubovicí. Mimo Chrudim je toto zboží doloženo i z areálu nedalekého benediktinského kláštera v Podlažicích (KT Podlažice 3 - Frolík-Musil-Sigl s. d.), zaniklého v dubnu roku 1421.

Do stejného časového úseku (tj. na přelom 13. a 14. století) můžeme zařadit oxidačně vypálené béžové zboží se sendvičovým efektem (KT 209, 5 ks, 55 g). Určitelné fragmenty bylo možné přiřadit pouze kuchyňské, převážně nezdobené keramice. Pouze v jednom př́ípadě byla zjištěna výzdoba v podobě oběžné šroubovice. Analogické soubory, ve kterých se tato keramika vyskytuje, známe z Dvakačovic (KT Dvakačovice 26 - Frolík-Musil-Sigl s. d.), z hradu Košumberka (KT Košumberk 209 - tamtéž), z Jezbořic (KT Jezbořice 3 - Frolík-Mácalová-Stránská 2016, 29-34) a z Lažan (KT Lažany 3 - Frolík 2019, 77-112).

Do průběhu 14. století můžeme datovat šedé keramické zboží s kožovitým přetahem se slídou a sendvičovým efektem (KT 212, 26 ks, 865 g). Kuchyňská keramika je zastoupena hrnci a kónickými mísami, keramika stolní zlomky džbánu. Okraje hrnců byly formovány do podoby nepravého okruží s vnitřním prožlabením (typ H351 - 1×; H381 - 2×), vyskytnou se ale i okraje ovalené s vnitřním prožlabením (typ H431 - 1×). V souboru byl registrován i zlomek vodorovného obloukovitého okraje mísy. Nádoby byly zdobeny oběžnou $(10 \times)$ a vývalkovou šroubovicí $(2 \times)$. Po technologické stránce se jedná o vyspělé zboží z větši části vytáčené na rychle rotujícím hrnčířském kruhu, které patrně produkovaly městské dílny snad z okruhu Čáslavi, Chotěboře či Ledče nad Sázavou. Tato charakteristická keramika se vyskytuje v širší oblasti mezi Ronovem nad Doubravou, Chrudimí a Skutčí. Silně zastoupena je v chrudimském městském prostředí (KT 212 - Frolík-Musil-Sigl s. d.), dále je zjištěna její př́tomnost na hradech Ohebu (KT Oheb 13 - tamtéž), Vildštejně (KT Vildštejn 5 - tamtéž),

1 Jsou to: 1) barva, 2) ostřivo, 3) barva lomu, 4) výpal, 5) povrch, 6) afinita s jinými technologickými skupinami. 
Košumberku (KT Košumberk 212 - tamtéž), Rabštejnku (KT Ra35 - Lacina-Musil v tisku), v areálu zaniklé vsi pod Sečskou přehradou (KT Seč 5 - Musil 2019), v Jezbořicích (KT Jezbořice 1 - Frolík-Mácalová-Stránská 2016, 29-34), u kostela sv. Václava v Lažanech (KT Lažany 1 - Frolík 2019, 77-112) či v okolí Ronova nad Doubravou (KT Rol - Malina-Musil-Netolický 2019).

Do stejného časového období patří i specifické světle šedé vysoce slídnaté zboží typu Zbyslavec (KT 232, 41 ks, 1269 g). Kuchyňská keramika je zastoupena zlomky hrnců, stolní keramika zlomky džbánu. Z hlediska okrajové profilace sledujeme u hrnců poměrně značnou variabilitu. Nalezneme zde okraje římsovité (typ H223 - 1×), různé varianty okrajů vytažených a nepravých okruží s vnitřním prožlabením (typ H347 - 1×; H351 - 1×; H361 - 1×), okraje ovalené s vnitřním prožlabením (typ H422 - 1×; H441 - 1×) či okraje přehnuté ostré (typ H615 - 1×). Výzdobu tvořila oběžná $(2 \times)$ a vývalková šroubovice (1×). Po technologické stránce se jedná o vyspělé zboží z větši části vytáčené na rychle rotujícím hrnčířském kruhu, které patrně produkovaly městské dílny snad z okruhu Čáslavi, Chotěboře či Ledče nad Sázavou. Vyskytuje se v širší oblasti mezi Chrudimí a Ronovem nad Doubravou. Tato na první pohled výrazná skupina keramiky byla vymezena na základě výsledků záchranného archeologického výzkumu ve Zbyslavci (Cejpová 2008, 312). Nalezneme ji v Dvakačovicích (KT Dvakačovice 6 - Frolík-Musil-Sigl s. d.), na zaniklé středověké vsi Bolešově (KT Bolešov 3 - Musil-Netolický 2012), na hradech Ohebu (KT Oheb 10 - Frolík-Musil-Sigl s. d.), Košumberku (KT Košumberk 232 -tamtéž) a Rabštejnku (KT Ra34 - Lacina-Musil v tisku), v souboru ze zaniklého benediktinského kláštera v Podlažicích (KT Podlažice 6 - Frolík-Musil-Sigl s. d.), ze zaniklé vsi pod Sečskou přehradou (KT Seč 2 - Musil 2019) či v okolí Ronova nad Doubravou (KT Ro9 - Malina-Musil-Netolický 2019).

Obecně do období 14. století lze zařadit stopově zastoupené obtáčené oxidační keramické zboží bez slídy s hrubším písčitým ostřivem (KT 205, 1 ks, 3 g). Mimo Chrudim máme doložen jeho výskyt např́iklad v souboru z areálu zaniklého benediktinského kláštera v Podlažicích (KT Podlažice 9-Frolík-Musil-Sigl s. d.) nebo od kostela sv. Václava v Lažanech (KT Lažany 10 Frolík 2019, 77-112). Technologicky vyspělejší je obdobně datovatelné hlazené oxidační zboží se slídou (KT 206, 1 ks, 2 g). Doklady tohoto zboží registrujeme např́iklad v nedalekém Hrochově Týnci (KT Hrochův Týnec 4 - Frolík-Stránská-Švédová 2018), v Jezbořicích (KT Jezbořice 2 Frolík-Mácalová-Stránská 2016, 29-34), v areálu kláštera v Podlažicích (KT Podlažice 10 - Frolík-Musil-Sigl s. d.), na hradě Košumberku (KT Košumberk 206 - tamtéž) či v Lažanech (KT Lažany 6 - Frolík 2019, 77-112).

Významné místo v souboru z jímky 962 zaujímá částečně obtáčené protoredukční keramické zboží tmavších tónů (KT 230, 115 ks, 2891 g), které registrujeme i na dalších soudobých lokalitách na Chrudimsku. V souboru je zastoupena keramika kuchyňská, stolní i technická. Kuchyňská keramika je reprezentována hrnci, pokličkami a mísami, stolní keramika poháry a technická zlomkem kahanu. $\mathrm{Z}$ hlediska okrajové profilace sledujeme u hrnců značnou tvarovou variabilitu. Dominují okraje vytažené a nepravá okruží s vnitřním prožlabením (typ H311 - 1×; H321 - 2×; H344 - 1×; H355 - 1×; H371 - 3×; H372 - 2×; H373 - 1×; H385 - 1×), méně jsou zastoupeny okraje ovalené s vnitřním prožlabením (typ H411 - 1×; H431 - 4×; H432 - 3×). U mísy byl zjištěn okraj obloukovitý široký vodorovný (typ M231 - 1×), u pokliček okraj šikmo seříznutý (typ Pk 23 $1 \times$ ), u kahanu okraj jednoduchý oble zesílený (typ Kh $11-1 \times$ ). Výzdoba sestává z oběžné $(3 \times)$ a vývalkové šroubovice $(8 \times)$. Toto zboží nalezneme např́íklad mezi nálezy $\mathrm{z}$ areálu ZSV Bolešova (KT Bolešov 4 - Musil-Netolický 2012), ze zaniklého benediktinského kláštera v Podlažicích (KT Podlažice 15 - Frolík-Musil-Sigl s. d.), z hradu Rabštejnka (KT Ra27 - Lacina-Musil v tisku), z Košumberka (KT Košumberk 230 - Frolík-Musil-Sigl s. d.), Ohebu (KT Oheb 18 - tamtéž), tvrziště Stoupec (KT Stoupec 4 - Musil-Netolický 2014) či z areálu Lhoty u Skutče (KT Lhota u Skutče 5 - Musil 2017) a z Dvakačovic (KT Dvakačovice 23 - Frolík-Musil-Sigl s. d.).

Do stejného období můžeme zařadit i nezdobené, tmavé opticky tvrdě vypálené vytáčené keramické zboží (KT 229, 3 ks, 19 g). Nalezneme ho např́iklad na hradě Košumberku (KT Košumberk 229-Frolík-Musil-Sigl s. d.), Ohebu (KT Oheb 14 - tamtéž), v Dvakačovicích (KT Dvakačovice 16tamtéž), Liboměřicích (KT Liboměřice 3 - tamtéž) či v Křižanovicích (KT Křižanovice 5 - tamtéž). 
Do stejného období by spadal výskyt v našem souboru stopově zastoupeného oranžového obtáčeného zboží (KT 221, 2 ks, 32 g). Jeden zlomek nese výzdobu v podobě vývalkové šroubovice. Analogické nálezy pocházejí z hradů Rabštejnka (KT Ra12 - Lacina-Musil v tisku) a Košumberka (KT Košumberk 221 - Musil 2018, 82).

Do druhé poloviny 14. a do počátku 15. století můžeme zařadit světlé oxidačně vypálené zboží s přetaženým krupičkovitým povrchem (KT 218, 66 ks, 2096 g). Kuchyňská keramika je zastoupena hrnci a stolní keramiku reprezentují zlomky poháru. Okraje hrnců byly formovány do podoby okraje jednoduchého (typ H151 - 1×), doloženy jsou nepravá okruží s vnitřním prožlabením (typ H351 - 1×; H371 - 1×; H373 - 4×), okraje přehnuté oblé (typ H735 - 1×) či různé varianty okrajů kyjovitých (typ H832 - 1×; H836 - 1×; H851 - 1×). V sedmi př́padech bylo doloženo užití oběžné šroubovice, jednoduchých či zdvojených rytých linií, v jedenácti prrípadech užití vývalkové šroubovice a čtyřrikrát výzdoby provedené ozubeným kolečkem (typ $18-2 \times$ ). Tato keramika je poměrně rozšířená. Velice četná je v chrudimském městském prostředí, silně je zastoupena v souboru ze zaniklé vsi pod Sečskou přehradou (KT Seč 6 - Musil 2019), z Dvakačovic (KT Dvakačovice 14 - Frolík-Musil-Sigl s. d.), z hradů Rabštejnka (KT Ra36 - Lacina-Musil v tisku), Ohebu (KT Oheb 6 - Frolík-Musil-Sigl s. d.), Vildštejna (KT Vildštejn 6 - tamtéž) a Košumberka (KT Košumberk 218 - tamtéž). Známe ji i z četných nalezišt' na Skutečsku, např́íklad ze Lhoty u Skutče (KT Lhota u Skutče 3 - Musil 2017), dále z Nových Hradů (KT NH13 - Frolík-MusilSigl s. d.) i z okolí Ronova nad Doubravou (KT Ro14 - Malina-Musil-Netolický 2019).

Do stejného časového intervalu můžeme zařadit tvrdě vypálené keramické zboží s kožovitým povrchem (KT 219, 41 ks, 792 g), které se částečně kryje s okruhem světlé oxidační keramiky zdobené červeným malovaným dekorem (srov. níže KT 213). V souboru je doložena kuchyňská keramika reprezentovaná hrnci, dále keramika technická zastoupená drobným zlomkem kahanu. Z hlediska okrajové profilace sledujeme u hrnců převahu variant nepravého okruží s vnitřním prožlabením (typ H381 - 1×; H386 - 1×; H387 - 2×; H393 - 1×) nad okraji ovalenými s vnitřním prožlabením (typ H444 - 1×) a kyjovitými (typ H832 - 1×). V sedmi případech bylo doloženo užití oběžné šroubovice, jednoduchých či zdvojených rytých linií, v jednom př́padě užití vývalkové šroubovice. I toto keramické zboží je na Chrudimsku poměrně rozšířené. Nalezneme ho např́́klad v areálu zaniklé vsi pod Sečskou přehradou (KT Seč 9 - Musil 2019), Dvakačovicích (KT Dvakačovice 15 - Frolík-Musil-Sigl s. d.), Křižanovicích (KT Křižanovice 3 - tamtéž), v Lažanech (KT Lažany 5 - Frolík 2019, 77-112), na hradech Rabštejnku (KT Ra16 - Musil 2009), Košumberku (KT Košumberk 219 - Frolík-Musil-Sigl s. d.), Žumberku (KT Žumberk 16 - tamtéž), Ohebu (KT Oheb 24 - tamtéž) a Vildštejně (KT Vildštejn 7 - tamtéž), na Nových Hradech (KT NH10 - tamtéž), na obléhacím stanovišti pod hradem Lichnicí (KT P003 - Musil 2014), v areálu zaniklého benediktinského kláštera v Podlažicích (KT Podlažice 1 - Frolík-Musil-Sigl s. d.) i v okolí Ronova nad Doubravou poměrně rozšířené (KT Ro12 - Malina-Musil-Netolický 2019).

Do stejného období spadá i výskyt hrubšího oxidačního zboží (KT 220, 3 ks, 169 g), které reprezentují v souboru pouze nezdobené zlomky kuchyňské keramiky. Rozpoznány byly pouze hrnce, jeden zlomek okraje je tvarován do podoby okruží (typ H13). Analogické nálezy jsou z regionu známy z hradů Rabštejnka (KT Ra9 - Lacina-Musil v tisku), Košumberka (KT Košumberk 220 - Musil 2018, 82) a Nových Hradů (KT NH3 - Frolík-Musil-Sigl s. d.), dále z Dvakačovic (KT Dvakačovice 20 - tamtéž), z Jezbořic (KT Jezbořice 6 - Frolík-Mácalová-Stránská 2016, 29-34) a z Lažan (KT Lažany 7 - Frolík 2019, 77-112).

Tyto popisované keramické třídy odpovídají rozložení distribučních zón vymezených v minulosti P. Vařekou (1998, obr. 1). Podle něj sever našeho území zaujímá oxidační tvrdě pálená keramika, jih šedá redukční a pruh mezi nimi tvoří hrubá stř̌edně tvrdě oxidačně pálená keramika. V tomto pásmu by se měla podle $\mathrm{P}$. Vařeky nalézat ještě Č́slav a přilehlá východní část středních Čech (Vařeka 1998, 132).

Období od konce 14. století znamená v chrudimské materiální kultuře masivní př́liv tmavého redukčního zboží z různých produkčních oblastí (Čáslav, Chotěboř, Ledeč nad Sázavou). 
V našem souboru se projevují celkem čtyři keramické technologické třídy (KT 214-217), které se od sebe liší kvalitou výpalu, použitým ostřivem a úpravou povrchu.

Dominantní keramickou skupinou konce 14. a první poloviny 15. století je redukční keramika ostřená pískem (KT 215, 339 ks, 7436 g). Je zastoupena jak keramika kuchyňská, tak i keramika stolní. Sortiment kuchyňské keramiky zahrnuje hrnce, zvonovité pokličky a kónické mísy, stolní keramiku reprezentují džbány. U hrnců se setkáváme s okraji vytaženými, nepravým okružím s vnitřním prožlabením (typ H321 - 1×; H325 - 2×; H351 - 1×; H354 - 1×; H372 - 1×; H373 - 1×; H381 - 1×), okruží (typ H524 - 1×), s okraji ovalenými s vnitřním prožlabením (typ H421 - 2×; H431 - 6×; H432 - 5×; H441 - 2×), s přehnutými oblými (typ H615 - 1×) a kyjovitými okraji (typ H833 - 2×; H841 - 1×; H851 - 1×). U pokliček rozeznáváme různé varianty okrajů šikmo seříznutých (typ Pk21 - 2×; Pk22 - 1×; Pk23 - 1×), mísy byly opatřeny širokými vodorovnými oblými okraji. U džbánů rozeznáváme okraje členěné (typ D221 - 1×; D222 - 1×) a okruží (typ D521 - 2×). Nádoby byly zdobeny pomocí rytých linií ( $8 \times$ a vývalkové šroubovice $(11 \times)$. S touto keramikou produkovanou pravděpodobně městskými dílnami snad z okruhu Č́slavi, Chotěboře či Ledče nad Sázavou se setkáváme např́íklad v areálu zaniklé vsi pod Sečskou přehradou (KT Seč 8 - Musil 2019), v Dvakačovicích (KT Dvakačovice 5 - Frolík-Musil-Sigl s. d.), na hradech Košumberku (KT Košumberk 215 - tamtéž), Ohebu (KT Oheb 19 - tamtéž), Vildštejně (KT Vildštejn 4 - tamtéž), Rabštejnku (KT Ra25 - Lacina-Musil v tisku) a Strádově (KT Strádov 9 - Musil 2016) či u kostela sv. Václava v Lažanech (KT Lažany 4 - Frolík 2019, 77-112).

V první polovině 15. století se na Chrudimsku setkáváme s vyspělou, na kruhu točenou redukčně vypalovanou hrnčinou s písčitým ostřivem v keramickém těstě (KT 214, 52 ks, 653 g). Jedná se o kuchyňskou keramiku reprezentovanou pouze hrncovitými nádobami. Z hlediska okrajové profilace rozeznáváme okraje $\mathrm{v}$ podobě nepravého okruží s vnitřním prožlabením (typ H351 - 1×), okruží (typ H513 - 1×; 532 - 1×) a okraje přehnuté oblé (typ H735 - 1×). Nádoby byly zdobeny oběžnou šroubovicí či svazkem vodorovných rytých linií $(2 \times)$, poprrípadě vývalkovou šroubovicí $(2 \times)$. $S$ touto keramikou produkovanou pravděpodobně městskými dílnami snad z okruhu Čáslavi se setkáváme např́iklad v Dvakačovicích (KT Dvakačovice 18 - Frolík-MusilSigl s. d.), na hradech Košumberku (KT Košumberk 214 - tamtéž), Ohebu (KT Oheb 7 - tamtéž), Vildštejně (KT Vildštejn 3 - tamtéž) a Rabštejnku (KT Ra31 - Lacina-Musil v tisku) či v areálu obléhacích prací pod hradem Lichnicí (KT P004 - Musil 2014).

Souběžně, ale v menší míře se v souboru vyskytuje i redukční zboží s kožovitým povrchem (KT 216, 135 ks, 4155 g). V sortimentu kuchyňské keramiky se objevují hrnce, zvonovité pokličky a mísy, keramiku stolní reprezentují džbány a jeden zlomek okraje poháru jihlavského typu. Okraje hrnců jsou tvarově značně variabilní. Setkáváme se s okraji římsovitými (typ H222 - 1×), s nepravým okružím s vnitřním prožlabením (typ H351 - 1×; H355 - 1×; H355 - 1×; H381 - 1×; H393 - 1×), s ovalenými okraji s vnitřním prožlabením (typ H431 - 1×; H444 - 2×), dále s okraji kyjovitými (typ H831 - 1×; H832 - 1×; H852 - 2×). U pokliček shledáváme okraje jednoduché oble zesílené (typ Pk13 - 1×), u mísy okraje široké vodorovné oblé (typ M231 - 1×) a okraje ovalené (typ M421 -2×). U džbánů byl registrován okraj v podobě okruží (typ D521 - 1×), u poháru jihlavského typu s trojúhelníkovitým ústím jednoduchý zaoblený okraj (typ H111 - 1×). Nádoby byly zdobeny svazkem vodorovných rýh $(2 \times)$ a vývalkovou šroubovicí $(13 \times)$. Mimo chrudimské městské prostředí se s ním setkáváme v areálu ZSV Bolešov (KT Bolešov 4 - Musil-Netolický 2012), na obléhacím stanovišti pod hradem Lichnicí datovaném do let 1428-1429 (KT P002 - Musil 2014), v Dvakačovicích (KT Dvakačovice 24 - Frolík-Musil-Sigl s. d.), na hradě Košumberku (KT Košumberk 216 - tamtéž), v areálu podlažického kláštera zaniklého v roce 1421 (KT Podlažice 14 tamtéž) či v okolí Kovářova (KT Kovářov 3 - Musil-Netolický 2016).

Skupinu režného redukčního zboží uzavírá kovově šedé či černé leštěné vysoce kvalitní keramické zboží (KT 217, 177 ks, 4868 g), často nesoucí výzdobu provedenou pomocí ozubeného kolečka. Sortiment kuchyňské keramiky zastupovaly hrnce, pokličky a mísy, keramiku stolní džbány. U hrnců sledujeme poměrně značnou variabilitu utváření okrajové profilace. Nalezneme zde okraje jednoduché (typ H111 - 1×), římsovité (typ H222 - 1×; H261 - 1×), v podobě nepravého okruží (typ H351 - 1×; 
H354 - 1×) i pravého okruží (typ H552 - 1×; H591 - 1×), okraje ovalené s vnitřním prožlabením (typ H431 - 2×; H441 - 4×), okraje přehnuté oblé (typ H731 - 1×; H732 - 2×), okraje zavinuté a kyjovité (typ H811 - 1×; H832 - 3×; H836 - 2×; typ H842 - 1×). Pokličky byly opatřeny šikmo seříznutým okrajem (typ Pk21 - 2×), mísy ovaleným okrajem (typ M421 - 1×). Výzdoba sestávala z prostých vodorovných rytých linií $(9 \times)$, ve dvou případech ještě kombinovaných s radélkovou výzdobou v podhrdlí nádob. Ve dvou případech byla registrována vývalková šroubovice. Nejcharakterističtějším znakem této keramiky je výzdoba provedená pomocí ozubeného kolečka, která se vyskytla celkem $\mathrm{v}$ osmi prŕpadech (typ $13-1 \times ; 14-1 \times ; 18-1 \times ; 19-1 \times ; 30-1 \times$; neurč. $-3 \times$ ). Četné analogie nalezneme zejména v Č́slavi (Pavlů 1982, obr. 7-10; 1991), v Ledči nad Sázavou (Nechvátal 1967; ChvátalRous-Vokáč-Zimola 2013) nebo na hradě Lipnici (Nekuda-Reichertová 1968, obr. 53). Po Chrudimi pochází největší publikovaný soubor této keramiky z hradu Rabštejnka (KT Ra4 - Musil 2009; 2013; Lacina-Musil v tisku). Mimo to se vyskytuje na hradech Ohebu (KT Oheb 4 - Frolík-Musil-Sigl s. d.), Nových Hradech (KT NH4 - tamtéž), Rychmburku (KT Rychmburk - tamtéž), Košumberku (KT Košumberk 217 - tamtéž), Vildštejně (KT Vildštejn 2 - tamtéž) a Žumberku (KT Žumberk 1 tamtéž), v zaniklé středověké vsi Bolešově (KT Bolešov 5-Musil-Netolický 2012), v ploše obléhacího tábora pod hradem Lichnice (KT P001 - Musil 2014), v zaniklém klášteře v Podlažicích (KT Podlažice 7 - Frolík-Musil-Sigl s. d.), v Lažanech (KT Lažany 13 - Frolík 2019, 77-112), ve Lhotě u Skutče (KT Lhota u Skutče 2 - Musil 2017), v Hrochově Týnci (KT Hrochův Týnec 8 - Frolík-Stránská-Švédová 2018), v Jezbořicích (KT Jezbořice 5-Frolík-Mácalová-Stránská 2016, 29-34), v okolí Kovářova (KT Kovářov 1 - Musil-Netolický 2016), v Křižanovicích (KT Křižanovice 4 - Frolík-Musil-Sigl s. d.), v Dvakačovicích (KT Dvakačovice 4 - tamtéž), v Liboměřicích (KT Liboměřice 2 - tamtéž), v areálu zaniklé středověké vsi pod Sečskou přehradou (KT Seč 3 - Musil 2019), Ronově nad Doubravou (KT Ro4 - Malina-Musil-Netolický 2019) a v Trhové Kamenici (KT TK 4 - Musil 2011a; 2011b).

Pouze obecně do období 14.-15. století můžeme zařadit nálezy z okruhu světlé až bílé keramiky s červeným malováním (KT 213, 20 ks, 464 g). Tato ve středověku velmi oblíbená keramika byla současně vyráběna na různých místech naší republiky (Gabriel-Smetana 1983). V popisovaném souboru byly rozpoznány zlomky kuchyňské i stolní keramiky. Kuchyňskou keramiku zastupují zlomky hrnců s páskovým prožlabeným uchem v podhrdlí s prostou malovanou linkou a dále zlomky zvonovitých pokliček. Keramiku stolní reprezentují džbány. Z hlediska okrajové profilace u hrnců sledujeme okraje jednoduše profilované (typ H141 - 1×), nepravá okruží s vnitřním prožlabením (typ H371 - 1×), okruží (typ H521 - 1×), ovalené s vnitřním prožlabením (typ H431 - 2×) či kyjovité (typ H851 - 1×). Okraje pokliček jsou jednoduše profilované, zesílené (typ Pk13 - 1×). Malovanou výzdobu v podobě jednoduchých linek v podhrdlí doplňuje oběžná šroubovice (1×). I toto keramické zboží bylo na Chrudimsku velmi oblíbené. Mimo Chrudim je nalezneme v Lažanech (KT Lažany 12 - Frolík 2019, 77-112), v areálu ZSV Bolešov (Bolešov 2 - Musil-Netolický 2012), v Trhové Kamenici (KT TK3 Musil 2011a; 2011b), v Rozhovicích (Frolík 1984, obr. 29; 30:2), v Jezbořicích (KT Jezbořice 4 Frolík-Mácalová-Stránská 2016, 29-34), v Hrochově Týnci (KT HT 12 - Frolík-Stránská-Švédová 2018), v areálu zaniklého benediktinského kláštera v Podlažicích (KT Podlažice 2 - Frolík-MusilSigl s. d.), v Dvakačovicích (KT Dvakačovice 3 - tamtéž), z hradního prostředí zmiňme Košumberk (KT Košumberk 213 - tamtéž), Nové Hrady (KT NH2 - tamtéž), Rychmburk (KT Rychmburk 2 tamtéž), Žumberk (KT Žumberk 7 - tamtéž), Oheb (KT Oheb 3 - tamtéž), Rabštejnek (KT Ra18 Lacina-Musil v tisku) a Strádov (KT Strádov 14 - Musil 2016).

Obdobně oblíbené bylo i charakteristické zboží severomoravského výrobního okruhu (Goš 2007; KT 224, 1 ks, 5 g), které je v souboru z jímky 962 zastoupeno pouze jedním drobným zlomkem z těla hrnce. Mimo Chrudim nalézáme jeho doklady v Dvakačovicích (KT Dvakačovice 19 - Frolík-Musil-Sigl s. d.), z areálu zaniklého kláštera v Podlažicích (KT Podlažice 8 - tamtéž) a z hradů Košumberka (KT Košumberk 224 - tamtéž), Ohebu (KT Oheb 5 - tamtéž), Nových Hradů (KT NH8 - tamtéž), Vildštejna (KT Vildštejn 1 - tamtéž), Rychmburka (KT Rychmburk 5 tamtéž), Žumberka (KT Žumberk 14 - tamtéž), Rabštejnka (KT Ra14 - Lacina-Musil v tisku) a Strádova (KT Strádov 2 - Musil 2016), tedy napříč všemi sociálními vrstvami. O oblibě této keramiky na Chrudimsku hovoří i písemné prameny. Z privilegia Vladislava II. Jagellonského pro 
Chrudim datovaného do roku 1486 máme doložen prodej keramických výrobků z Loštic a Ledče nad Sázavou na chrudimském trhu (Nekuda-Reichertová 1968, 25; Goš 2007, 96).

Pouze obecně do období 14.-15. století můžeme zařadit drobný atypický zlomek kameniny (KT 225, 1 ks, 4 g) a oxidační částečně žlutě a žlutooranžově transparentně glazované keramické zboží (KT 227, 13 ks, 72 g). V případě glazovaného zboží KT 227 se ve všech případech jedná o doklady kuchyňské keramiky, tvořené trojnožkami a hrnci. U trojnožek sledujeme okraje jednoduché kyjovité a s vnitřním prožlabením (typ P22 - 1×; P31 - 1×) a držadla typu 1 (1×). U hrnců bylo zjištěno tordování okraje (1×) a výskyt vývalkové šroubovice (1×). Mimo Chrudim máme toto zboží doloženo v Hrochově Týnci (KT Hrochův Týnec 6 - Frolík-Stránská-Švédová 2018), v Jezbořicích (KT Jezbořice 7 - Frolík-Mácalová-Stránská 2016, 29-34), v Lažanech (KT Lažany 14 - Frolík 2019, 77-112), na hradě Košumberku (KT Košumberk 227 - Frolík-MusilSigl s. d.) a na Strádově (KT Strádov 11 - Musil 2016).

Nastupující raně novověkou keramickou produkcí konce 15. a první poloviny 16. století reprezentuje lokální specifické hnědočerveně transparentně glazované zboží typu Husova ulice (Frolík-Sigl 1990; Musil 2009; KT 226, 38 ks, 471 g), které v souboru zastupují fragmenty kuchyňské i stolní keramiky. Kuchyňskou keramiku reprezentují hrncovité nádoby a zlomky trojnožek, stolní keramiku reprezentuje zlomek džbánu. Z hlediska okrajové profilace u hrnců sledujeme výskyt kyjovitých okrajů (typ H831 - 1×; H842 - 1×), u trojnožek sledujeme okraje s vnitřním prožlabením a se žebrem (typ P21 - 1×; P51 - 1×; držadlo typ 1-1×). Z výzdobných motivů je po jednom prípadě doloženo užití rytých linií a vývalkové šroubovice. Analogické nálezy jsou v rámci regionu známy z výzkumů v Chrudimi (Frolík-Sigl 1990; Frolík-Kozáková-Musil 2009, 460), v Dvakačovicích (KT Dvakačovice 11 - Frolík-Musil-Sigl s. d.), v Jezbořicích (KT Jezbořice 8 - Frolík-MácalováStránská 2016, 29-34), v areálech hradů Rabštejnka (KT Ra8 - Musil 2009; Lacina-Musil v tisku), Košumberka (KT Košumberk 226 - Frolík-Musil-Sigl s. d.), Nových Hradů (KT NH5 - tamtéž), Ohebu (KT Oheb 26 - tamtéž), Vildštejna (KT Vildštejn 8 - tamtéž) a Žumberka (KT Žumberk 4 tamtéž) i z okolí Ronova nad Doubravou (KT Ro15 - Malina-Musil-Netolický 2019, 877-881).

Do průběhu 15. až počátku 16. století můžeme rovněž zařadit i poměrně hojně zastoupené jemné režné oxidační zboží (KT 231, 34 ks, 2231 g). V souboru nalezneme jak kuchyňskou, tak i stolní keramiku. Kuchyňská keramika je tvořena hrnci, stolní pak džbány. Z hlediska okrajové profilace sledujeme u hrnců výskyt okrajů v podobě nepravého okruží s vnitřním prožlabením (typ H372 - 1×), okruží (typ H521 - 1×) a okraje kyjovité (typ H851 - 1×). Výzdoba sestávala z rytých linií (1×), samostatné vývalkové šroubovice $(1 \times)$ a její kombinace s radélkem (typ $40-1 \times$ ). Tato keramika je známa ze ZSV Bolešov (KT Bolešov 6 - Musil-Netolický 2012), z okolí Kovářova (KT Kovářov 5 - Musil-Netolický 2016), ze Lhoty u Skutče (KT Lhota u Skutče 6 - Musil 2017), z Dvakačovic (KT Dvakačovice 13 - Frolík-Musil-Sigl s. d.), z Křižanovic (KT Křižanovice 2 - tamtéž), z hradu Košumberka (KT Košumberk 231 - tamtéž), Ohebu (KT Oheb 15 - tamtéž), Rabštejnka (KT Ra32 - Lacina-Musil v tisku), Strádova (KT Strádov 1 - Musil 2016), z tvrze Stoupec (KT Stoupec 6 - Musil-Netolický 2014), z velitelského stanoviště obléhatelů pod hradem Lichnicí (KT P008 - Musil 2014) či z okolí Ronova nad Doubravou (KT Ro5 - Malina-Musil-Netolický 2019).

Nejmladší složku souboru představuje glazované (KT 312) a režné novověké zboží (KT 320), které patří období 17. a 18. století.

Svébytné postavení v souboru zaujímají zlomky kachlů (obr. 7), které náleží dvěma keramickým technologickým třídám (KT 222 a KT 236). Zastoupeny jsou jak kachle komorové (4×), tak kachle baňkové $(2 \times)$ a kachle nádobkové s pravoúhlým ústím (52×).

Promítneme-li si výsledky této analýzy do stratigrafické situace, vyrýsují se nám zřetelně dva jasně oddělené horizonty (obr. 2). První, mladší představují uloženiny G6/125 až G6/138 (obr. 4). Z hlediska materiální náplně představují různorodou směs keramiky od raně středověké po raně novověkou keramiku. Druhý, starší horizont od uloženiny G6/139 po dno jímky je chronologicky mnohem semknutější, neobsahuje mladší nálezy, raně středověké nálezy se objevují pouze v minimální míře (obr. 5, 6, 7:8). Velice dobře je sledovatelný pohyb fragmentů nádob v ještě asi nepř́iliš soudržných fekálních výplních v úrovni uloženin G6/139 až G6/143. 

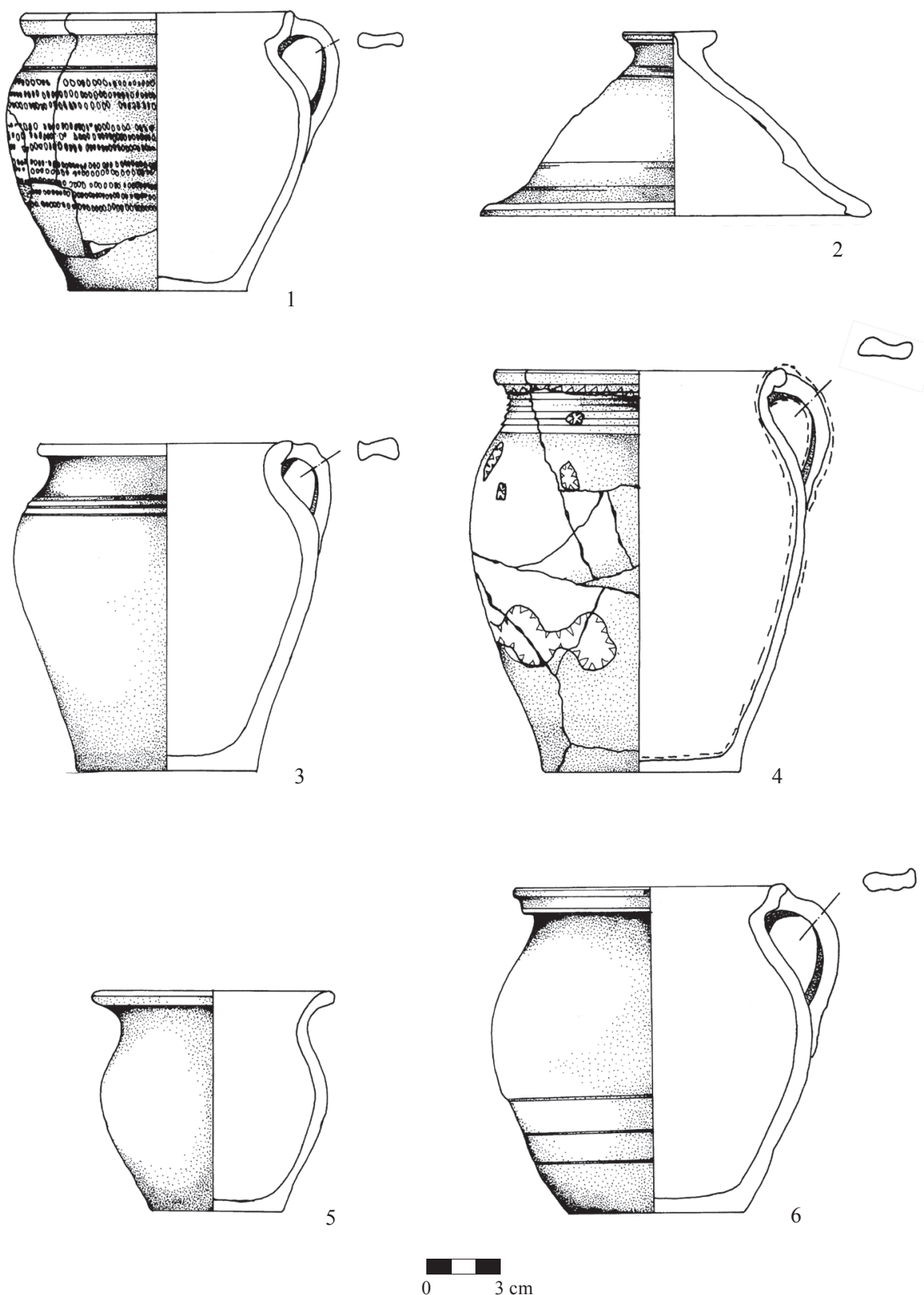

Obr. 4. Chrudim, Hradební ulice. Jímka 962. Výběr keramiky prvního (mladšího) horizontu. 1-3 - uloženina G6/128; 4-6 uloženina G6/136. Kresba B. Hlaváčová a P. Jakubková.

Abb. 4. Chrudim, Hradební-Straße. Abwassergrube 962. Keramikauswahl vom ersten (jüngeren) Horizont. 1-3 - Ablagerung G6/128; 4-6 - Ablagerung G6/136. Zeichnung B. Hlaváčová und P. Jakubková. 

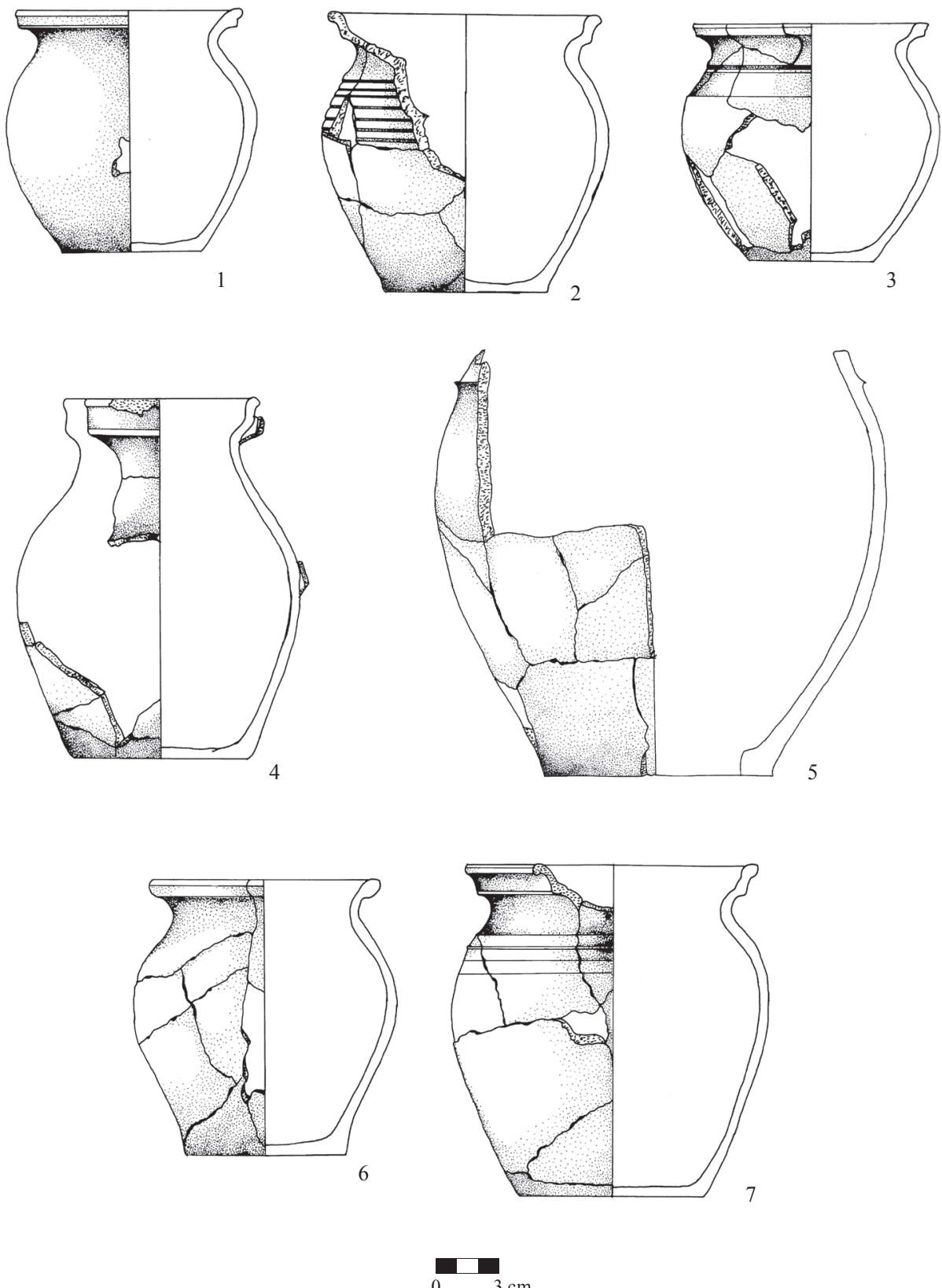

$3 \mathrm{~cm}$

Obr. 5. Chrudim, Hradební ulice. Jímka 962. Výběr keramiky druhého (staršího) horizontu. 1-3 - uloženina G6/139; 4-7 uloženina G6/140. Kresba B. Hlaváčová a P. Jakubková.

Abb. 5. Chrudim, Hradební-Straße. Abwassergrube 962. Keramikauswahl vom zweiten (älteren) Horizont. 1-3 - Ablagerung G6/139; 4-7 - Ablagerung G6/140. Zeichnung B. Hlaváčová und P. Jakubková. 

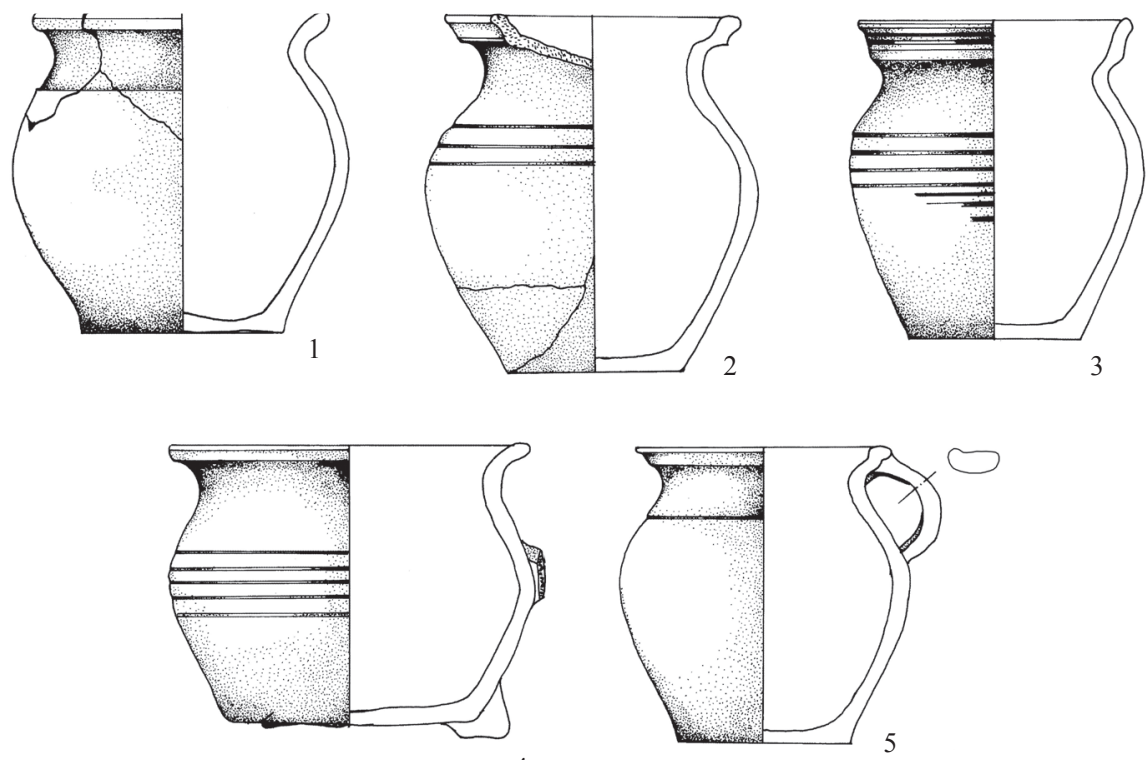

4
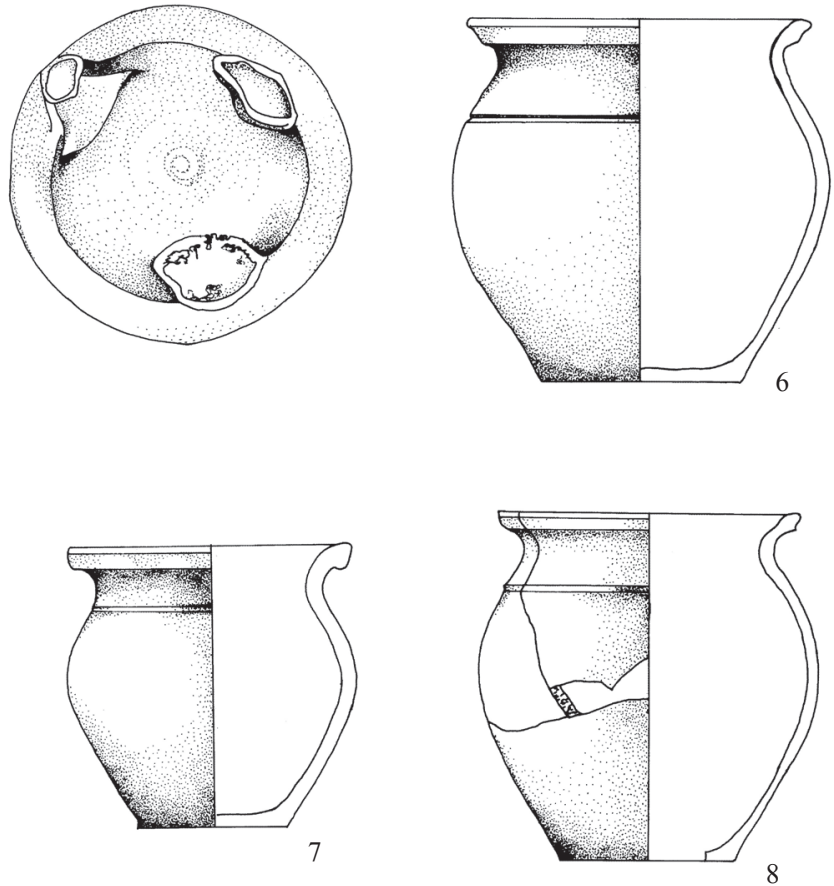

0

$3 \mathrm{~cm}$

Obr. 6. Chrudim, Hradební ulice. Jímka 962. Výběr keramiky druhého (staršího) horizontu. 1-5 - uloženina G6/140; 6-8 uloženina G6/143. Kresba B. Hlaváčová a P. Jakubková.

Abb. 6. Chrudim, Hradební-Straße. Abwassergrube 962. Keramikauswahl vom zweiten (älteren) Horizont. 1-5 - Ablagerung G6/140; 6-8 - Ablagerung G6/143. Zeichnung B. Hlaváčová und P. Jakubková. 


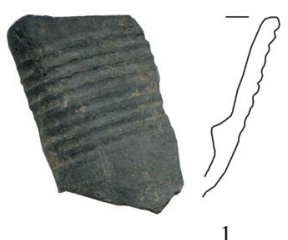

1

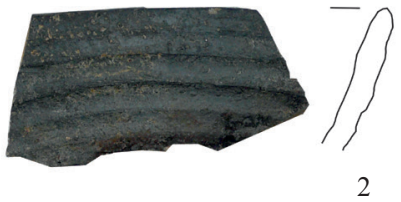

2

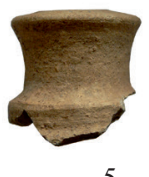

5
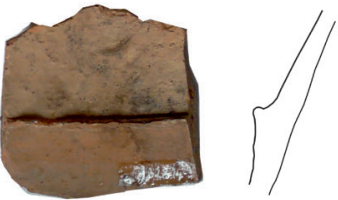

3

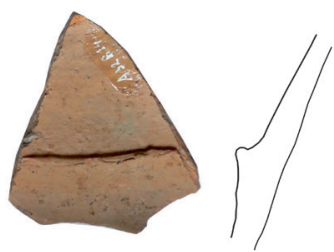

4
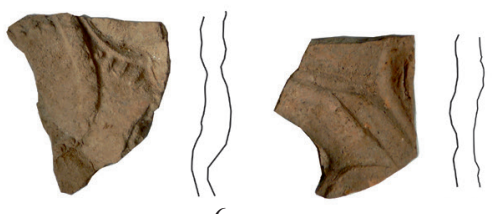

6
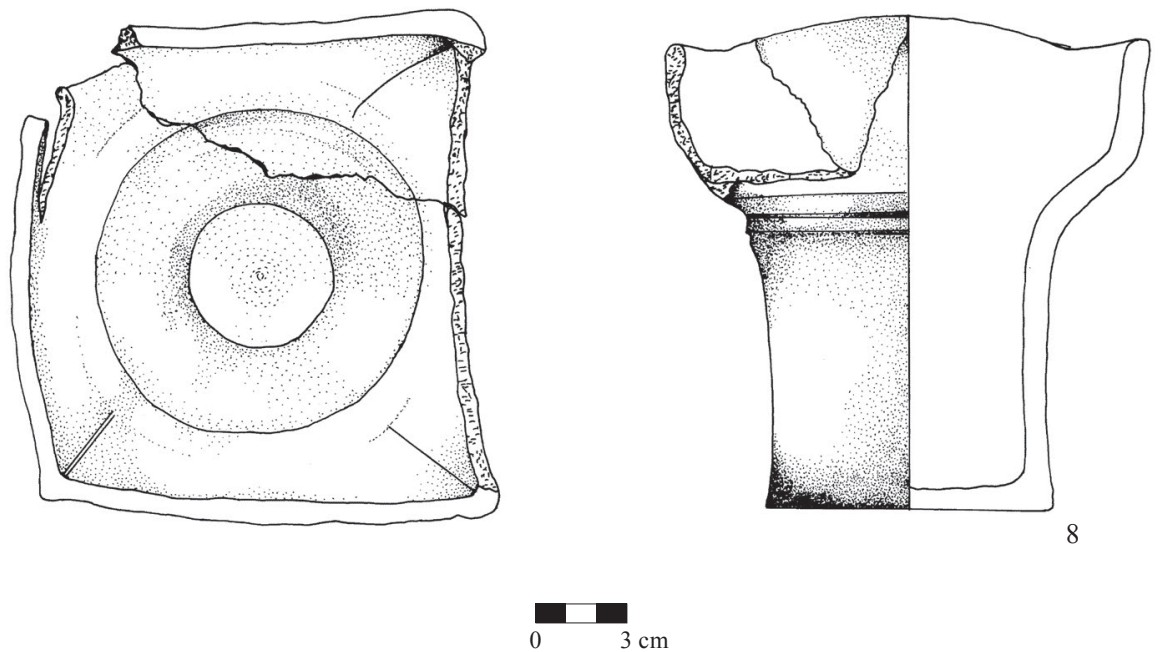

Obr. 7. Chrudim, Hradební ulice. Jímka 962. Výběr kachlů. 1-5 - uloženina G6/125; 6-7 - uloženina G6/126; 8 - uloženina G6/142. Foto J. Musil.

Abb. 7. Chrudim, Hradební-Straße. Abwassergrube 962. Auswahl an Kacheln. 1-5 - Ablagerung G6/125; 6-7 - Ablagerung G6/126; 8 - Ablagerung G6/142. Foto J. Musil.

\subsection{Sklo}

Odpadní jímka 962 ve čtverci G6 obsahovala vedle množství kuchyňské keramiky také četné fragmenty skleněných nádob z období 14. až 16. století. Získaný materiál lze na základě typologicko-chronologického vyhodnocení rozdělit do dvou horizontů. 
První (starší) horizont představuje sklo vrcholně a pozdně středověké, tedy sklo užívané v průběhu 14. a 15. století, které bylo nalezeno ve spodní části jímky, v uloženinách G6/135 až G6/144 (přičemž spodní vrstva G6/144 sklo prakticky neobsahovala). Nejvíce jsou zde zastoupeny pro toto období charakteristické číše českého typu a číše nebo číšky s taženými kapkami. Oba tyto tvary patří ve středověku mezi běžnou sklářskou produkci a byly poměrně hojně užívány v měšt’anských domácnostech ve 14. až 15 . století. Vedle nápojového skla z těchto vrstev pochází láhev zdobená hladkými vlákny.

Do druhého (mladšího) horizontu patří sklo z uloženin v horní polovině jímky - v rozmezí uloženin G6/134 až G6/126, které obsahovaly jak sklo středověké, tak raně novověké. Sklo středověké představují číše a číšky s taženými kapkami a zlomky číší českého typu. Unikátním nálezem je hrdlo láhve nebo konvice z kvalitního importovaného skla, která patřila mezi luxusní stolní sklo dostupné vyšším společenským vrstvám. Sklo renesančního tvarosloví zastupují především zlomky pohárů s polovejčitou nebo vřetenovitou kupou a zlomky válcovitých číší nebo číšek. Některé z těchto nádob jsou zdobeny optickým dekorem (především vertikálních žeber nebo čoček), který vznikl použitím kovové nebo dřevěné optické předformy. $Z$ tohoto smíšeného horizontu byly získány také fragmenty okenního skla - kruhových okenních terčíků a trojúhelníkových výplní používaných k sestavování vitrají.

Skleněné fragmenty byly nalezeny téměř ve všech vrstvách výplně jímky. Z vrstvy G6/144 pochází pouze zlomek číše českého typu zdobené nálepy a dva drobné zlomky dutého skla. Následující vrstva G6/143 již byla na sklo bohatší (41 ks) - vedle zlomků číše se svinutými nálepy a modrým vláknem ovinutým pod ústím (obr. 8:3) obsahovala také fragmenty nejméně dalších tří nádob. Dvě z nich - číše zdobená natavenou klikatkou (obr. 8:6) a číška s taženými kapkami, ze které se zachovaly zlomky lehce miskovitého okraje zdobeného modrým vláknem (obr. 8:5), jsou vyrobeny z mírně nazelenalého skla, které je na základě optického posouzení shodné se sklem použitým na výrobu číše s nálepy. Z číšky s taženými kapkami zřejmě pochází také vysoce vpíchnuté dno (obr. 8:12) a zlomky okraje a těla, které byly silně poškozeny korozí. Ani u jedné z těchto nádob se vzhledem $\mathrm{k}$ velké fragmentárnosti nepodařilo rekonstruovat původní tvar.

Číše a číšky s taženými kapkami patřily do základního sortimentu středověkých sklářských hutí v Čechách. V archeologických souborech se vzácně objevují již od 12. století, ale jejich počet vzrůstá až od druhé poloviny 13 . století. V oblibě se udržely až do první poloviny 15 . století. Alespoň částečně rekonstruovat se podařilo číši s taženými kapkami z vrstvy G6/142² - jedná se o vyšší variantu číší s válcovitým ústím a výrazně kyjovitě rozšířenou výdutí, která je od ústí oddělena hladkým modrým vláknem (obr. 8:2). Tělo číše je zdobeno taženými kapkami s modrými zrníčky. Ze stejné nádoby může pocházet i dno se spodní částí těla ovinutého modrým vláknem. Číše podobného tvaru, ale s menší baňatostí byly nalezeny např́iklad na tvrzi v Konůvkách a v Brně ve studni na Dominikánském náměstí, v kontextu datovaném mezi léta 1390-1430 (Sedláčková ed. 2019a, 284-285, Fig. IV.6.2). Vysoké kyjovité číše se zataženým okrajem jsou známy také z Prahy a Plzně (Haggrén-Sedláčková 2007, 208-209, obr. 3). Žádný z uvedených exemplářů ale nemá tak výrazně kyjovitou výdut' jako číše z Chrudimi.

Následující vrstvy G6/141 (10 ks) až G6/140 (30 ks) obsahovaly pouze drobné zlomky okrajů a patky blíže neurčitelné číše českého typu, okraj a dno číšky s taženými kapkami, kolem něhož bylo ovinuté hladké vlákno v několika řadách (obr. 8:10, 13), a zlomky píštalovité číše s modrým vláknem pod nízkým ústím a s tělem zdobeným natavenou klikatkou (obr. 8:7). Skleněné fragmenty se stejným dekorem pocházejí také z vrstvy G6/143, je tedy pravděpodobné, že se jedná o tutéž nádobu. Číše a číšky zdobené klikatkou nejsou v českém a moravském materiálu př́liš časté. V rámci chrudimských výzkumů bylo nádob zdobených klikatkou nalezeno více. Několik exemplářů z první poloviny 15. století pochází také z Olomouce (Sedláčková 2001, 416, obr. 2:5, 9). Motiv klikatky by použit i na zvláštní nádobě kulovitého tvaru na nožkách - grapenu - nalezené

2 Tato vrstva obsahovala také několik fragmentů výdutí a okraje číše se svinutými nálepy. 

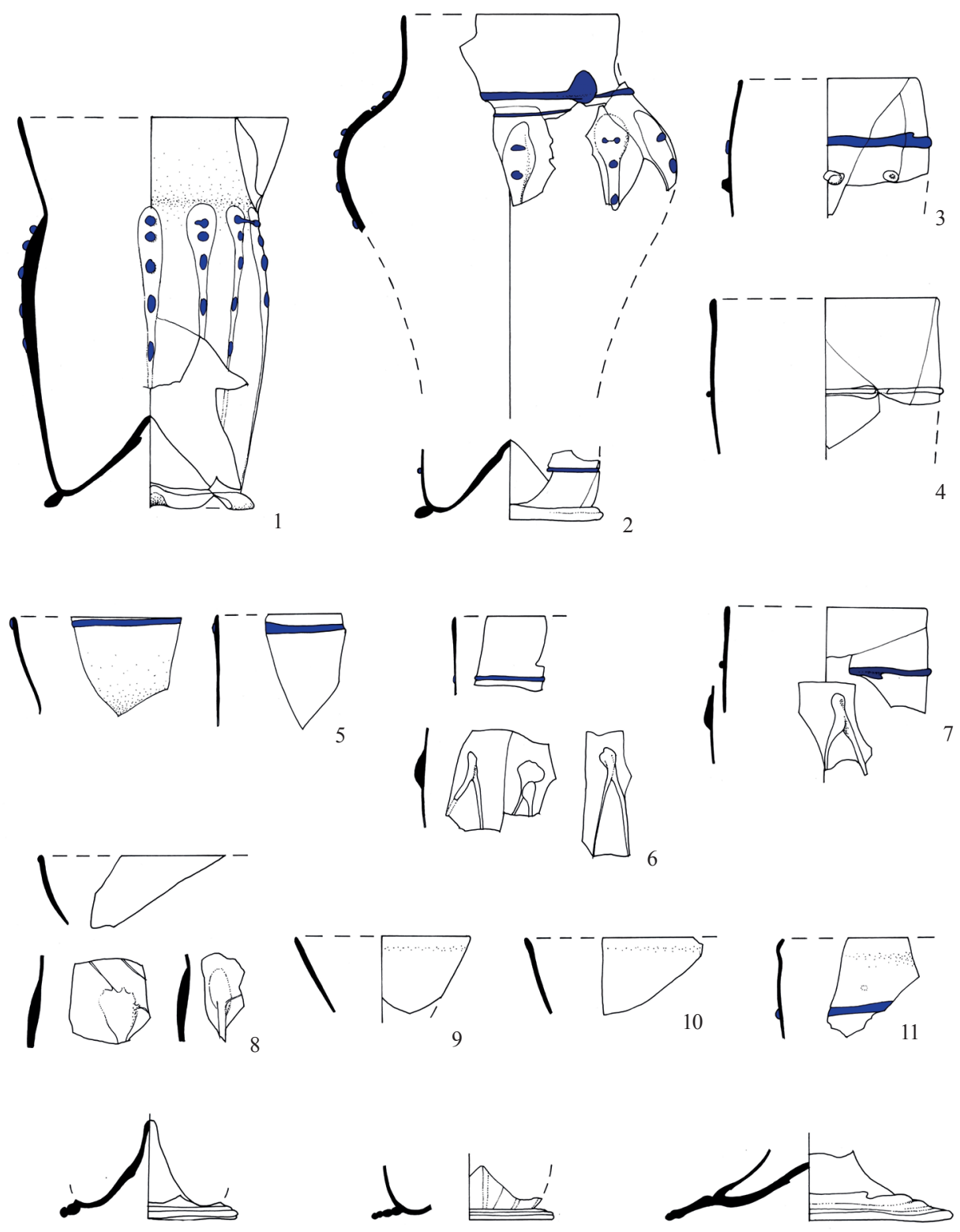

12

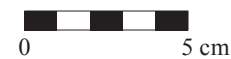

Obr. 8. Chrudim, Hradební ulice, jímka 962.1 - uloženiny G6/131+134; 2 - uloženina G6/142; 3, 5, 6, 12 - uloženina G6/143; 4 - uloženina G6/135; 7, 10, 13 - uloženiny G6/140+141; 8, 14 - uloženina G6/131; 9 - uloženiny G6/138+139; 11 - uloženina G6/128. Kresba K. Břečková.

Abb. 8. Chrudim, Hradební-Straße. Abwassergrube 962. 1 - Ablagerungen G6/131+134; 2 - Ablagerung G6/142; 3, 5, 6, 12 - Ablagerung G6/143; 4 - Ablagerung G6/135; 7, 10, 13 - Ablagerungen G6/140+141; 8, 14 - Ablagerung G6/131; 9 - Ablagerungen G6/138+139; 11 - Ablagerung G6/128. Zeichnung K. Břečková. 
na České ulici v Brně v jímce datované do 14. století (Himmelová 1991, Tab. I:2; Sedláčková 2006, 209, Fig. 6:12).

Ani soubor skla z vrstev G6/139 a G6/138 nebyl příliš početný (7 ks) - obsahoval pouze zlomek číše s taženými kapkami s modrými zrníčky a několik zkorodovaných zlomků okrajů nejméně dvou nádob - číšky a pravděpodobně láhve (obr. 8:9).

Více skla obsahovala vrstva G6/136 (ca 100 ks), kde bylo nalezeno hrdlo láhve spirálovitě ovinuté hladkým vláknem. Ze stejné nádoby zřejmě pocházely zlomky kulovitého těla zdobeného natavenou klikatkou ze silného vlákna (obr. 9:3-4). Láhve patřily vedle číší českého typu a číšek s taženými kapkami k nejrozšiřenějším tvarům dutého skla v českých zemích. Nejběžnější byly láhve s hruškovitým nebo kulovitým tělem bez výzdoby, ale objevovaly se i exempláře zdobené hutnickým dekorem. Láhve s plastickým dekorem klikatky však nepatří mezi běžné nálezy. Jeden exemplář s kulovitým tělem byl nalezen např́íklad v Ústí nad Labem, ve studni datované do 14. až počátku 15. století (Černá 1996, 20-21, obr. 11:1). Spolu s láhví byly ve vrstvě G6/136 nalezeny
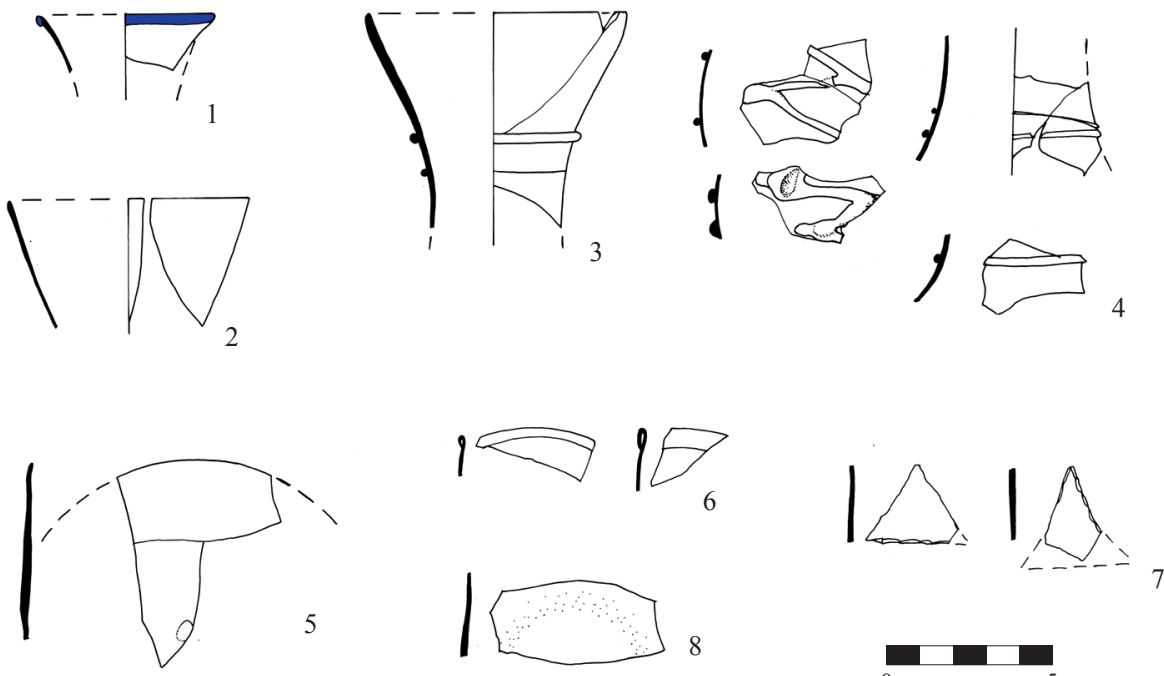

0
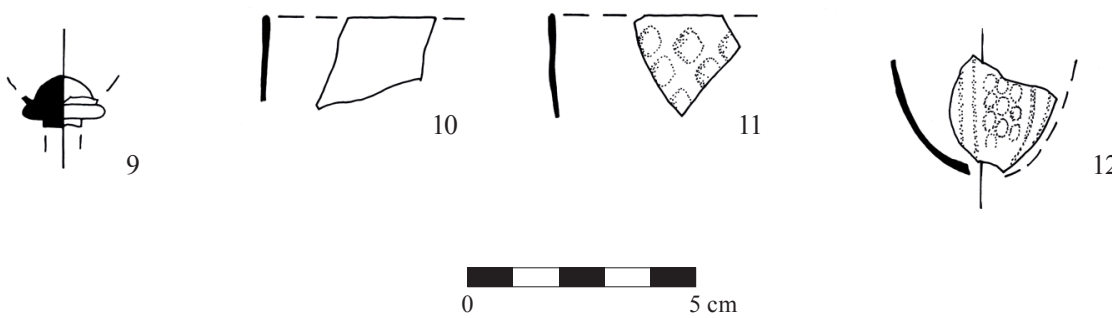

Obr. 9. Chrudim, Hradební ulice, jímka 962. 1, 5-7, 10-12 - uloženina G6/131; 2, 8, 9 - uloženina G6/134; 3, 4 - uloženina G6/136. Kresba K. Břečková.

Abb. 9. Chrudim, Hradební-Straße. Abwassergrube 962. 1, 5-7, 10-12 - Ablagerung G6/131; 2, 8, 9 - Ablagerung G6/134; 3, 4 - Ablagerung G6/136. Zeichnung K. Břečková. 
četné fragmenty píšłalovitých číší českého typu se svinutými nálepy. Všechny zlomky z této vrstvy byly silně zkorodované a svým charakterem se shodovaly s nálezy z mladší uloženiny G6/135, nad kterou již nasedaly smíšené vrstvy s obsahem skla gotického a renesančního tvarosloví. Vrstva G6/135 obsahovala pouze zlomky vysoké píšt’alovité číše se svinutými nálepy (31 ks, obr. 8:4) a zlomek výdutě s klikatkou (2 ks).

Z vrstvy G6/134 pochází již sklo typicky renesančních tvarů (14 ks) - dno kupy poháru (obr. 9:9), zlomky okraje poháru s nezdobenou vřetenovitou kupou z tenkostěnného bezbarvého skla (obr. 9:2) a střední část okenního terčíku z lehce nazelenalého skla (obr. 9:8). Vrstva G6/133 byla na nálezy skla chudá, obsahovala pouze jeden drobný zkorodovaný zlomek okraje číše nebo číšky.

Ve výše položené uloženině G6/131 byl nalezen chronologicky smíšený soubor skla (ca 200 ks a drt'). Středověké sklo je zastoupeno číší českého typu, z níž se zachovala patka (obr. 8:14), a číškou s miskovitým ústím a tělem zdobeným taženými kapkami (obr. 8:8). Soubor raně novověkého skla obsahuje více nádob, většinou drobných typicky renesančních tvarů nejméně tři číše nebo číšky zdobené optickým dekorem čoček a svislých žeber (obr. 9:10-11) a několik pohárů s vřetenovitou a polovejčitou kupou, z nichž jeden je zdoben optickým dekorem svislých žeber střídajících se s dekorem čoček (obr. 9:12). Rekonstruovat se podařilo pohár s polovejčitou kupou zdobenou svislými žebry z lehce nafialovělého skla. Stejně zdobené poháry byly nalezeny např́iklad v Opavě na Dolním náměstí 18 nebo v areálu novokřtěnského dvora ve Strachotíně (Sedláčková 2001a, obr. 4:0084). Tyto nálezy lze datovat do druhé poloviny 16. až první poloviny 17. století. Optický dekor vytvořený vyfouknutím nádoby do speciální předformy (tzv. optišky) s následným tvarováním (Hais R. a kol. 2010, 34) patřil v tomto období k velmi oblíbeným výzdobným technikám, nebot' umožňoval snadnou a rychlou výrobu velkého množství efektně zdobených nádob. Uplatňoval se nejen na nápojovém skle, jako byly drobné poháry a číšky, ale také na stolních láhvích, džbáncích, konvičkách a poutnických láhvích. Kromě skla dutého byly z vrstvy G6/131 získány i fragmenty okenních terčíků s jednoduchým zataveným okrajem a trojúhelníkovité výplně se zaštípanými hranami (obr. 9:5-7).

Ze zlomků nalezených ve vrstvách G6/131 a G6/134 bylo zrestaurováno torzo číšky s taženými kapkami z lehce nazelenalého skla. Jedná se o variantu se soudkovitým tělem a miskovitým ústím (obr. 8:1). Č́šska je vysoká $15 \mathrm{~cm}$, tělo bylo zdobené 15 kapkami (dochovalo se ale jen 14) a na každé z nich je nataveno pět modrých zrníček. Kolem vpíchnutého dna je ovinuté hladké vlákno. Tato varianta nádob s taženými kapkami patřila mezi nejrozšířenější. Většinou mají kolem okraje ovinuté modré vlákno, ale výjimkou nejsou ani exempláře bez této úpravy. Č́šsy s taženými kapkami a se soudkovitým tělem jsou známy z Kutné Hory (Lehečková 1975, obr. 3). Na rozdíl od rekonstruované chrudimské číšky ale mají některé kutnohorské exempláře kolem okraje natavené modré vlákno. Analogické nálezy jsou známy ze Solné ulice v Plzni, z Prahy (Hejdová a kol. 1983, 252, obr. 19; Žd’árská 2014, 105-106, obr. 5, obr. 18:3, obr. 40) a z Hradce Králové (Hejdová-Nechvátal 1967, 2, 468, obr. 7:7; Hejdová 1967, obr. 3:2). Číšky s taženými kapkami s modrými zrníčky jsou doloženy také v Mostě (Černá 1995, 253-254). Na Moravě byly číšky tohoto typu nalezeny např́íklad v Brně (Haggrén-Sedláčková 2007, 214, Fig. 6) a v Olomouci (Sedláčková 2001, 415-416, obr. 2:6). Velkou oblibu dokládá rozšíření tohoto typu číšek na území stř̌ední a severozápadní Evropy, Pobaltí a Skandinávie (Haggrén-Sedláčková 2007, 220-239).

Za unikátní nález lze považovat trychtýřovité ústí z bezbarvého skla s modrým zdobením z vrstvy G6/131, kde ovšem představuje starší prŕíměs (obr. 9:1). Hrdlo pochází z importované láhve typu Norimberk nebo konvice typu Mečová. Tyto nádoby mají téměř identický tvar, liší se pouze př́itomností trubicovité výlevky a ucha. Obě mají pod trychtýřovitým ústím vysoké hrdlo s vývalkem zdobené natavenými modrými a bezbarvými vlákny, cibulovitě klenuté tělo bývá zdobené jemnými žebry. Často se ale dochovaly pouze zlomky hrdla nebo ústí, stejně jako v př́ípadě chrudimského exempláře, což neumožňuje rozlišit tyto dva tvary. Láhve i konvice byly vyráběny z velmi kvalitního bezbarvého skla sodnovápenatého složení, které bylo používáno v prŕimořských oblastech jižní Evropy a Malé Asie. Stejné složení bylo prvkovými analýzami 
potvrzeno i u láhve z Hradební ulice. ${ }^{3}$ Nejvíce těchto výrobků bylo datováno do rozmezí let 1270-1350. Rozšířeny byly na území podél Dunaje, především v západním Mad’arsku, v Dolním Rakousku, na jižním Slovensku a jižní Moravě (viz Janovíčková-Sedláčková 2008). Tyto nádoby představovaly luxusní zboží dostupné pouze nejvyšším společenským vrstvám. Také v Čechách byly nalezeny v prostředí nejvyšší světské společnosti - na Pražském hradě, v Kutné Hoře-Hrádku, v Táboře (Janovíčková-Sedláčková 2008, 274) a Plzni (Frýda 2007, 46, Tab. 5: 4-6). Početněji jsou zastoupeny na Moravě, především v Brně (Janovíčková-Sedláčková 2008, 269-270), ale doloženy jsou i Kroměříži.

Z mladší vrstvy G6/128 byl získán pouze zlomek okraje číšky a zlomek okraje a těla číše českého typu zdobené svinutými nálepy. I tato číše měla, stejně jako další exempláře z jímky 962 , ústí ovinuté hladkým modrým vláknem (obr. 8:11). Ze svrchní vrstvy G6/126 pocházel pouze neurčitý zlomek bezbarvého dutého skla.

Pro určení počtu nádob nebylo možné se striktně držet rozdělení výplně podle stratigrafických uloženin, nebot' velká část nádob byla složena z fragmentů pocházejících z různých částí jímky. Celkem lze z jímky 962 identifikovat nejméně deset skleněných nádob z období vrcholného a pozdního středověku - z toho minimálně dvě číše českého typu zdobené nálepy, jednu číši zdobenou natavenou klikatkou, další dvě číše, které nebylo možné blíže popsat, a minimálně tři číše či číšky s taženými kapkami. Kromě nápojového skla jímka obsahovala silně zkorodované torzo láhve zdobené hutnickým dekorem, hrdlo další láhve a okraj láhve typu Norimberk / konvice typu Mečová. Sklo raně novověké bylo ve velmi fragmentárním stavu a většina nálezů představovala běžnou sklářskou produkci - jednoduché renesanční tvary pohárů nebo číšek bez dekoru, př́ípadně s optickým dekorem. Pravděpodobná sériovost výroby (např. picí soupravy) značně komplikovala určení počtu nádob, ze kterých fragmenty pocházely. Odhadem se zde ale nacházelo sedm až osm nádob a několik okenních terčíků.

Skleněné nálezy z jímky 962 odpovídají vybavení lepší běžné měšt’anské domácnosti v období středověku. Obdobné nálezové soubory jsou známy z řady významných měst, například Brna, Opavy, Olomouce. Je nutné poznamenat, že srovnatelné spektrum skleněných výrobků pochází i z dalších chrudimských jímek. Jistě nepřekvapí výrazně převažující zastoupení domácích výrobků, jedná se však často o ne zcela běžné tvary či typy zdobení. Jediný import představuje láhev z kvalitního bezbarvého skla, která se do Chrudimi zřejmě dostala z jihoevropských (pravděpodobně benátských) skláren. Mladší období pak představuje zcela běžnou měštanskou domácnost, př́ípadně může menší množství nálezů souviset s vybíráním jímky.

\subsection{Kovy a ostatní materiály}

Z výplně jímky 962 byl vyzdvižen nevelký soubor kovových nálezů, a to železných a bronzových. Převážnou část železných předmětů představují hřebíky (37 kusů) a neurčitelné amorfní zlomky (3 kusy). Většinu hřebíků představují zlomky, u nichž není možné určit jejich typ. Pokud se přidržíme rozdělení výplně jímky na výše definované části, tak ve starší části (uloženiny G6/143 až G6/135) zjišt'ujeme celkem šest hřebíků neurčeného typu (44 g - obr. 11:1, 12, 14, 17-19) a tři amorfní zlomky (7 g - obr. 11:2, 3, 13). Ani u jednoho hřebíku nemůžeme určit jeho typ. Amorfní zlomek z uloženiny G6/143 je pravděpodobně součástí jakési trubičky (obr. 11:3). Největším a nejtěžším předmětem (173 g) je bronzový svorníkový pružinový závěsný zámek (obr. 10:21). Tělo je dochováno v úplnosti, odlomena je jedna bočnice a chybí také břevno svorníku. Zámek byl v této podobě nepoužitelný, a proto byl zřejmě odhozen. Chronologicky se nejedná o citlivý předmět, může být zařazen do širšího období 14.-15. století. Soubor kovových nálezů doplňují dvě bronzové hrudky (2 g-obr. 11:15, 16).

3 Složení skel nasvědčuje původu těchto nádob v severoitalských sklárnách. Absence láhví typu Norimberk v Itálii lze vysvětlit výrobou na objednávku konkrétních zákazníků. 

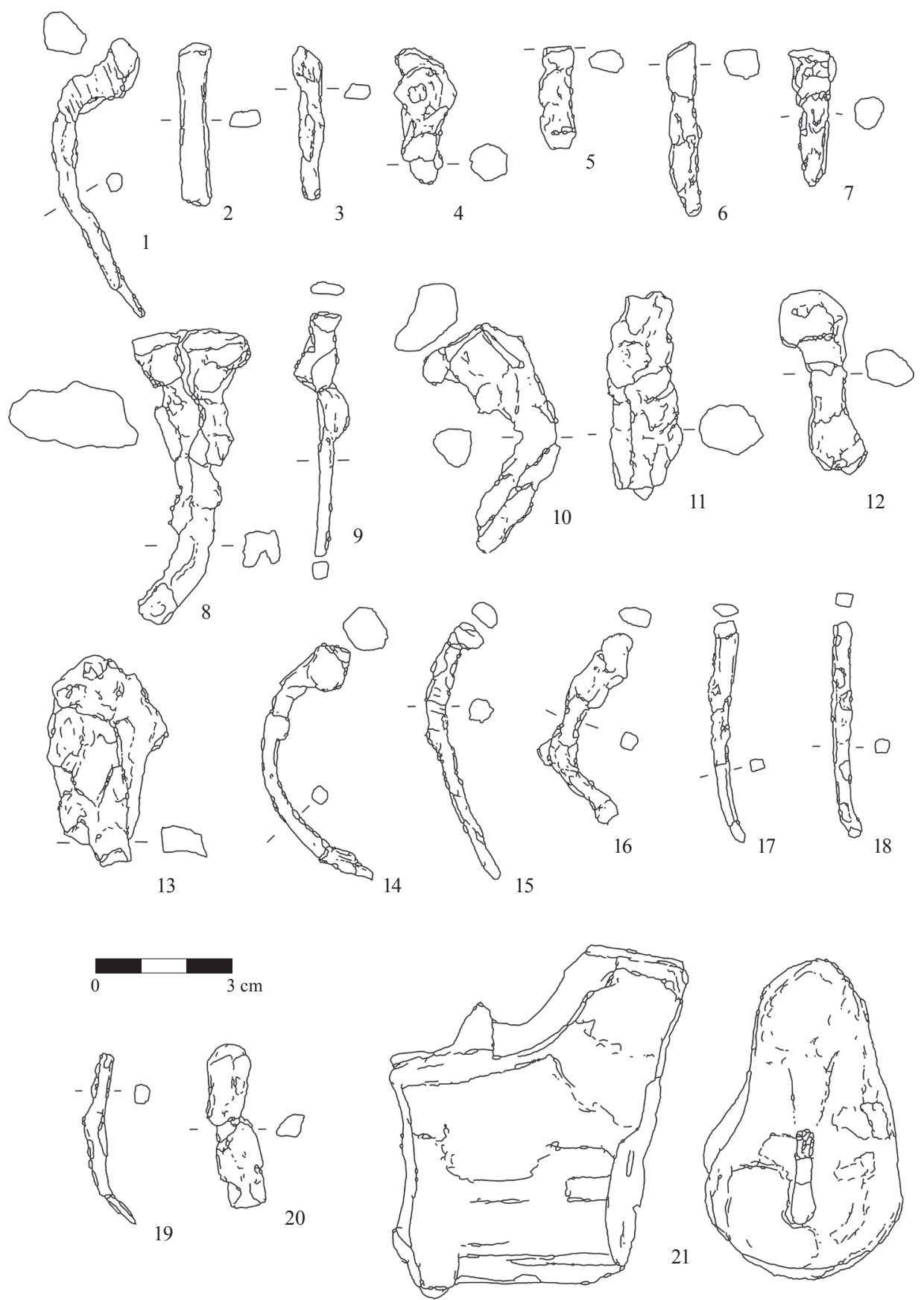

Obr. 10. Chrudim, Hradební ulice, jímka 962. 1-13 - hřebíky, uloženina G6/128; 13-20 - hřebíky, uloženina G6/131; 21 visací zámek, uloženina G6/135; 21 - bronz, ostatní železo. Kresba J. Frolík.

Abb. 10. Chrudim, Hradební-Straße. Abwassergrube 962. 1-13 - Nägel, Ablagerung G6/128; 13-20 - Nägel, Ablagerung G6/131; 21 - Hängeschloss, Ablagerung G6/135; 21 - Bronze, der Rest Eisen. Zeichnung J. Frolík. 

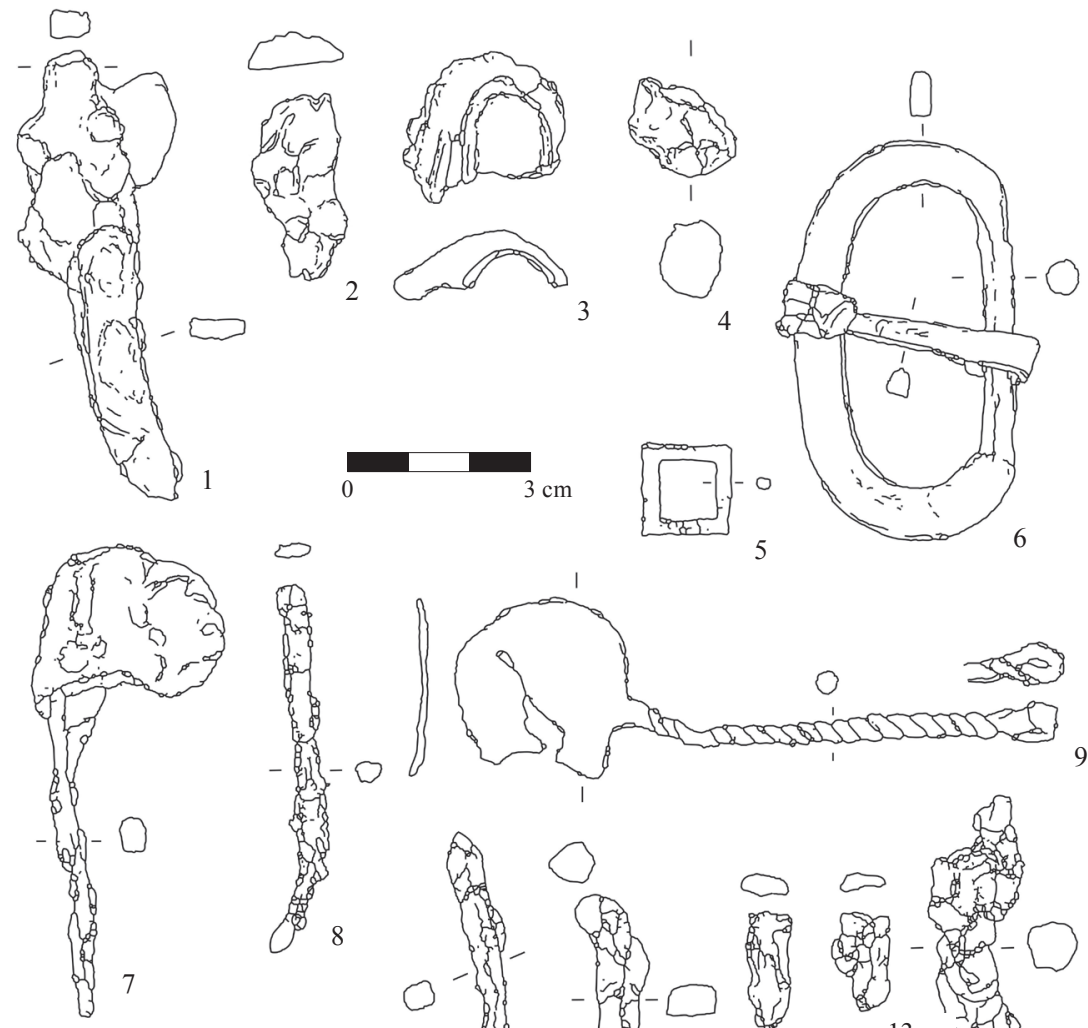

5
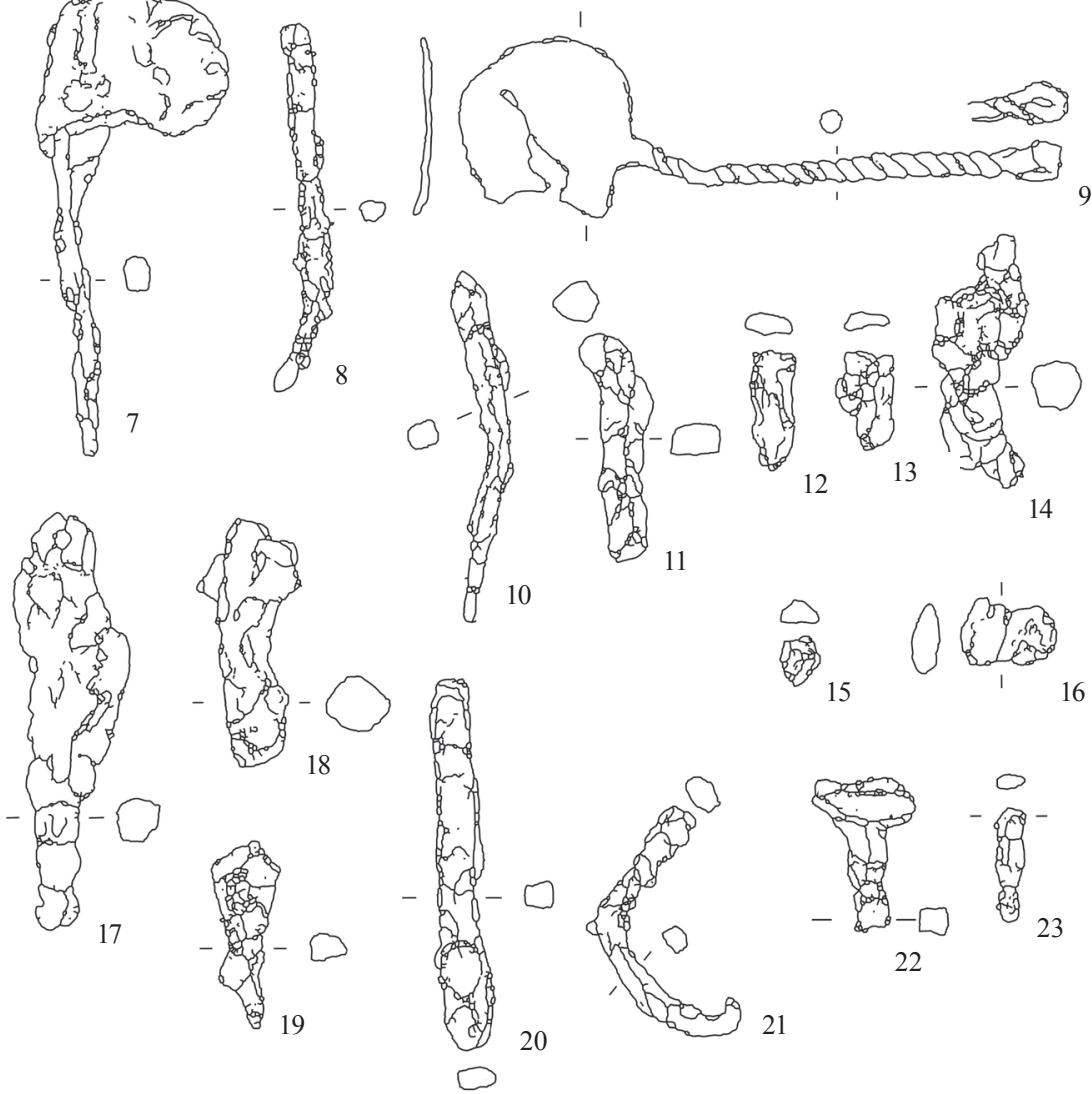

12
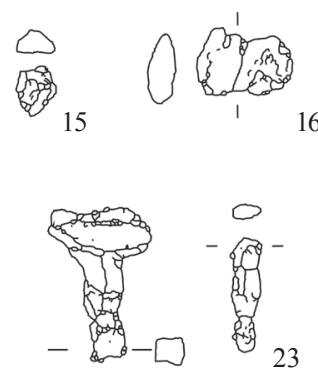

22

Obr. 11. Chrudim, Hradební ulice, jímka 962. 1 - hřebík, uloženina G6/143; 2,3 - amorfní zlomky, uloženina G6/143; 4 - slitek, uloženina G6/128; 5 - přezka, uloženina G6/131; 6 - přezka, uloženina G6/128; 7 - hřebík, uloženina G6/127; 8, 10, 11, 20-23 hřebíky, uloženina G6/126; 9 - lžička s tordovanou rukojetí, uloženina G6/131; 12, 13, 17-19 - hřebíky, uloženina G6/136; 14 amorfní zlomek, uloženina G6/136; 15, 16 - slitky, uloženina G6/135; 4, 5, 15, 16 - bronz, ostatní železo. Kresba J. Frolík.

Abb. 11. Chrudim, Hradební-Straße. Abwassergrube 962. 1 - Nagel, Ablagerung G6/143; 2, 3 - amorphe Bruchstücke, Ablagerung G6/143; 4 - Ofensau, Ablagerung G6/128; 5 - Schnalle, Ablagerung G6/131; 6 - Schnalle, Ablagerung G6/128; 7 Nagel, Ablagerung G6/127; 8, 10, 11, 20-23 - Nägel, Ablagerung G6/126; 9 - Löffel mit tordiertem Griff, Ablagerung G6/131; 12, 13, 17-19 - Nägel, Ablagerung G6/136; 14 - amorphes Bruchstück, Ablagerung G6/136; 15, 16 - Ofensäue, Ablagerung G6/135; 4, 5, 15, 16 - Bronze, der Rest Eisen. Zeichnung J. Frolík. 
Ze střední části výplně (uloženiny G6/134 až G6/131) známe kovové předměty pouze z uloženiny G6/131. Bylo z ní vyzdviženo sedm hřebíků (16 g-obr. 10:14-20), z nichž u tř́i nelze určit typ (klasifikace podle Krajíc 2003, 61-69). Po jednom jsou zastoupeny typy IV, VC, VI a VIIID. Jedná se o velmi rozšiřrené typy užívané při stavebních pracích. Typ VC je označován jako ,šindelák“, typ VI sloužil k připevňování podkov nebo pantů. Do souboru kovových nálezů patří také drobná bronzová čtvercová přezka (2 g), sloužící ke spojení subtilního pásku, například k připevnění ostruhy k obuvi (obr. 11:5). Podobné se objevují ve 13.-16. století (Šlancarová 2018, 391-395). Zajímavým předmětem je malá plochá lžička s tordovanou rukojetí zakončenou očkem $(8 \mathrm{~g})$. Vyrobena byla ze železa a původně pravděpodobně pokovena (obr. 11:9). Lžička mohla být užívána při nabírání nějakého nevelkého množství (koření a podobné substance). V měštanské domácnosti se nabízí užití při stolování. Z Chrudimska známe analogickou z hradu Rychmburka (k. ú. Předhradí). Její datování se odvíjí od existence hradu, který je doložen od roku 1325 (Frolík 1982, 17).

Důležitým předmětem je také bronzové lotové závaží z uloženiny G6/131 (16 g, tj. 1 lot, obr. 12:1), které je blízké jiným nálezům z téhož výzkumu (jímka D2; Dáňová-Pražáková 2019, 38). Lotová závaží mají univerzální tvar a jednotlivé kusy se liší pouze velikostí, eventuálně značkami označujícími váhovou jednotku (Doležel 2008). Exemplář z jímky 962 je nezdobený a lze ho zařadit $\mathrm{k}$ nálezům pokročilého 13.-15. století.

Třetí, stratigraficky nejmladší část výplně (uloženiny G6/130 až G6/125) poskytla relativně nejpočetnější soubor, v němž opět převažují hřebíky (21 kusů, $108 \mathrm{~g}$ ) s převahou neurčitelných zlomků (obr. 10:1-13; obr. 12:7-8, 10-11, 20-23). Určit můžeme hřebíky typů IB (1 kus), IC (1 kus), IIIA (1 kus), IV (1 kus), VC (3 kusy) a VIIIB (2 kusy). Platí pro ně totéž co pro předchozí skupinu, nově evidované typy souvisí nejčastěji se stavebními pracemi, což je v souladu s charakterem uloženin, z nichž byly vyzdviženy. Soubor doplňuje masivní oválná přezka s trnem $(22 \mathrm{~g})$ z uloženiny G6/128 (obr. 11:6). Jedná se o běžný typ přezky ve tvaru D, která mohla být použita na opasku, ale i na koňském postroji (Šlancarová 2018, 302-358). V téže uloženině byl nalezen amorfní bronzový slitek ( $6 \mathrm{~g}$ - obr. 11:4). Opět se jedná o chronologicky necitlivé předměty, které se mohou vyskytovat v celém období doloženém nekovovými nálezy (14.-16. století).

Ojediněle je zastoupena také kost, a to hracím kamenem - astragalem s nepravidelným plankonvexním otvorem ve střední části (obr. 12:2) z uloženiny G6/133, tj. střední části souvrství (Hoch ed. 2020, 45, 121). Jedná se o chronologicky necitlivý předmět, který je $\mathrm{v}$ archeologických nálezech znám od doby římské až do novověku (Čechura 2015, 49, 73, 91-94; Filipová 2017, 61-65; Knápek-Šedo 2018; Švecová 2001). Nejjednodušší varianta hry spočívala ve vyhození kůstek dlaní vzhůru a pochytání co největšího počtu padajících kůstek hřbetem ruky. Další verze hry tkvěla v posbírání co největšího množství kůstek během letu vyhozených kůstek do vzduchu. Jinou možností byla obdoba hry na kuželky (Hoch ed. 2020, 44).

\section{Závěr}
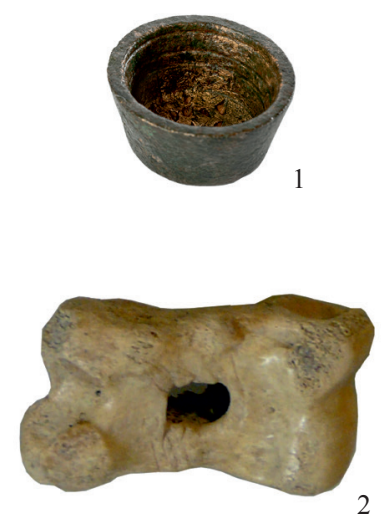

Na malém dvorku zaniklého čp. 15/I byla prozkoumána jediná jímka 962. Řez výplní jímky ukazoval bez detailnějšího posouzení

Obr. 12. Chrudim, Hradební ulice. Jímka 962. 1 - lotové závaží; 2 - hrací kámen - astragalus. Foto J. Musil.

Abb. 12. Chrudim, Hradební-Straße. Abwassergrube 962. 1 - Lotgewicht; 2 - Spielstein - Astragalus. Foto J. Musil. 
spíše na plynulé zaplňování s možným zarovnáváním deprese po sesedání výplně v horní části (uloženiny G6/125-G6/128). Charakter jednotlivých uloženin ukázal na rozdíl mezi spodní částí výplně s vyšším zastoupením organické složky (uloženiny G6/143-G6/135) a horní částí výplně s vyšším podílem kamenů (uloženiny G6/134-G6/125) s možným rozdělením na dvě dílčí etapy podle zastoupení úlomků cihel (uloženiny G6/134-G6/131 a G6/130-G6/125). Rozbor nálezů však ukazuje na zaplňování jímky ve 14. století ve spodní polovině (až do úrovně uloženiny G6/135). Následně zřjejmě došlo k částečnému vybrání obsahu a novému zaplňování, a to v 16. století. Při té př́ležitosti vzniklo souvrství s promíšeným obsahem s nálezy 14.-16. století (nejméně v rozsahu uloženin G6/131-G6/134). Výše evidované uloženiny obsahují jen mladší materiál 16. století (tj. od uloženiny G6/130 výše). Určitý rozdíl zjišt’ujeme u keramiky a skla. V př́ipadě keramiky se promíšené soubory objevují v rozsahu uloženin G6/125 až G6/138, u skla je to v rozsahu G6/125 až G6/134. Vysvětlení snad můžeme hledat ve skutečnosti, že hmotnější keramické zlomky nebo torza nádob se mohla snáze propadnout do starších uloženin. Obdobné rozdíly byly zjištěny u jednotlivých horizontů keramiky a skla také u jímky 938 (Frolík-Kozáková-Musil 2018). Nálezy rovněž nepotvrzují, že by horní část výplně vznikla jako důsledek dodatečného zaplňování prolákliny po sesedlé výplni.

Nálezový soubor představuje běžný středověký sortiment jen s minimálním výskytem vzácných nebo luxusních předmětů (láhev typu Norimberk či konvice typu Mečová, importovaná německá keramika). Nedovoluje určit, jaké bylo řemeslo majitele parcely v období před nejstarší písemnou zmínkou. Je možné, že se podílel na obchodních transakcích, jak naznačuje lotové závaží. Na základě provedené paleoparazitologické analýzy můžeme konstatovat, že obyvatelé domu čp. 15/I byli napadeni běžnými parazity v důsledku nedostatečné hygieny (Bartošová a kol. 2011, Fig. 10).

Př́tomnost pouze jediné jímky navozuje otázku, kam byl ukládán odpad produkovaný domácností v čp. 15/I. Nálezová situace neumožňuje předpokládat přítomnost dalších odpadních jímek, jako je tomu např́iklad na parcele domu čp. 14/I (Frolík-Kozáková-Musil 2018). Větší počet odpadních jímek chronologicky pokrývajících období od druhé poloviny 13. století do přelomu 16. a 17. století na jedné parcele zjistil výzkum ve Filištínské ulici v letech 1996-1997 (Černá 2005; Frolík-Sigl 1996). Jedinou jímku zjištujeme také u objeveného zaniklého domu na zahradě u domu čp. 10/I, kde velikost parcely rovněž nedovoluje uvažovat o dalších odpadních jímkách. Zdejší jímka 943 však byla mimořádně hluboká $(7 \mathrm{~m})$. S domem čp. 15/I spojuje tuto parcelu rohová pozice. Jako víceméně jediná možnost se jeví periodické vyprazdňování jímky, a to v nejstarším období (před 14. stoletím) a v období 15.-16. století. Dvě dochované etapy výplně můžeme považovat za náhodně uchovaný vzorek původně bohatšího a početnějšího obsahu.

Jímka 962 je dalším případem vyprázdněné a opakovaně použité odpadní jímky, který byl poprvé rozeznán u již zmíněné jímky 938 v Chrudimi (Frolík-Kozáková-Musil 2018) a následně také u odpadních jímek na jiných lokalitách (např. Praha - Cymbalak-Matějková 2012). Potvrzuje se tím důležitost pečlivé terénní práce a detailní dokumentace bez ohledu na její pracnost.

Tato práce byla podpořena Grantovou agenturou České republiky, číslo GA 19-05677S „Sklo v českých zemích od gotiky do baroka podle nálezů v Chrudimi a Brně. Význam regionální produkce v evropském kontextu“"

\section{Přehled keramických technologických tříd}

\section{Nezařaditelné 001-}

001

omleté poškozené

002 přepálené 


\section{Raný a vrcholný stř̌edověk 2}

\section{1 středohradištní hlazená}

1. černohnědá, hnědá

2. písčité ostřivo (do $1 \mathrm{~mm}$ ), slída jemně mletá (menší než $0,5 \mathrm{~mm}$ ) v těstě a vystupuje i na povrch

3. hnědočervený

4. opticky středně tvrdý, redukční, obtáčení

5. pečlivě upravený až hlazený povrch

6. CRF1, Dražkovice 6, Hrochův Týnec 3

\section{2 středohradištní nehlazená}

1. černohnědá, hnědá, černošedá

2. písčité ostřivo (až $1,5 \mathrm{~mm}$ ), větší množství středně mletého slídnatého ostřiva (šupinky až $1 \mathrm{~mm}$ )

3. černý

4. redukční, opticky středně tvrdý, obtáčení

5. nehlazený, středně hrubý povrch, ostřivo vystupuje na povrch

6. CRF2, Dražkovice 5, Dvakačovice 22, Košumberk 202(?), Podlažice 19

\section{3}

1. hnědá, hnědošedá, šedohnědá

2. písčité ostřivo (až $1,5 \mathrm{~mm}$ ), slída se koncentruje v povrchové části střepu

3. hnědý, hnědošedý (jako barva povrchu)

4. redukčně oxidační, opticky tvrdý

5. pečlivě upravený, střední až jemný, obtáčení, slída se koncentruje v povrchové části střepu

6. CRF3, Dražkovice 2, Dražkovice 3, Hrochův Týnec 2, Lažany 8, Licibořice 2

\section{4 bez slídy}

1. hnědá, hnědošedá, šedohnědá

2. písčité ostřrivo (až $4 \mathrm{~mm}$ ), absence slídy

3. hnědý, hnědošedý (jako barva povrchu)

4. redukčně oxidační, opticky tvrdý

5. pečlivě upravený, střední až jemný, obtáčení

6. CRF4, Dražkovice 8, Hrochův Týnec 1, Lažany 9, Podlažice 11

205

1. světle hnědá, hnědá

2. hrubší písčité ostřivo (až $1,5 \mathrm{~mm}$ ), dutiny až $1 \mathrm{~mm}$, absence slídy

3. hnědý, hnědošedý (jako barva povrchu)

4. opticky měkký, oxidačně redukční

5. pečlivě upravený, střední až jemný, obtáčení

6. CRF5, Lažany 10, Podlažice 9

\section{6 oxidační slídnatá hlazená se sendvičovým efektem}

1. světle hnědá, hnědá hnědošedá okrová 
2. písčité ostřivo (až $1 \mathrm{~mm}$ ), velmi jemně mletá slída v těstě i na povrchu (šupinky do $1 \mathrm{~mm}$ ), sendvičový efekt

4. oxidační se sendvičovým efektem, opticky měkký

5. hlazený pečlivě upravený povrch, slída i na povrchu, modelační rýžky, vytáčení(?)

6. CRF6, Hrochův Týnec 4, Jezbořice 2, Košumberk 206, Lažany 6, Podlažice 10

\section{7 středočeské zboží s krupičkovitým povrchem}

\section{1. hnědá}

2. písčité ostřivo ca $0,5 \mathrm{~mm}$, jemně mletá slída stopově

3. hnědočervený (jako povrch)

4. oxidační, opticky tvrdý, obtáčení

5. střední pečlivě upravený krupičkovitý povrch, ostřivo vystupuje na povrch, modelační rýžky na vnitřní straně

6. CRF7, zboží s kalichovitou profilací středočeské a pražské oblasti

\section{9}

1. béžová, okrová, světle hnědá

2. písčité ostřivo (1-3 mm), absence slídy, dutinky

3. černé až šedé jádro, sendvičový efekt

4. oxidační, sendvičový efekt, obtáčení, vytáčení

5. střední povrch, krupičkovitý

6. CRF9, Dvakačovice 26, Jezbořice 3, Košumberk 209, Lažany 3

\section{0}

1. hnědá, tmavě hnědošedá a šedohnědá

2. písčité ostřivo $(1-2 \mathrm{~mm})$, velmi jemně mletá slída

3. sendvičový efekt, šedé jádro

4. oxidační, sendvičový efekt, obtáčení, vytáčení

5. jemný až hladký povrch pečlivě upravený, modelační rýžky

6. CRF10, blízká 206, Dvakačovice 25, Hrochův Týnec 5, Košumberk 210, Lažany 2, Lhota u Skutče 1, Podlažice 21

\section{2 kožovitá se slídou}

1. světle béžově šedá, místy černošedá

2. písčité ostřivo (až $2 \mathrm{~mm}$ ), slída se koncentruje v povrchové části střepu

3. černošedé jádro, sendvičový efekt, velmi tenkostěnný

4. oxidační, sendvičový efekt, opticky tvrdý

5. jemný povrch, kožovitý přetah, vysoce slídnatý v na povrchu

6. CRF12, Jezbořice 1, Košumberk 212, Lažany 1, Oheb 13, Ra35, Ro1, Seč 5, Vildštejn 5

\section{3 bílá červeně malovaná}

1. bělavá, bílá, béžová až světle okrová

2. kamínky $0,05-1,5 \mathrm{~mm}$, dutinky

3. bělavá, bílá, béžová až světle okrová

4. oxidační, opticky tvrdý

5. hladký, vytáčení 
6. CRF13, Bolešov 2, Dvakačovice 3, Hrochův Týnec 12, Jezbořice 4, Košumberk 213, Lažany 12, NH2, Oheb 3, Podlažice 2, Ra18, Rychmburk 2, Strádov 14, TK3, Žumberk 7

\section{4 redukční se slídou čáslavského okruhu}

1. světle béžově šedá, místy černošedá

2. písčité ostřivo, slídnaté ostřivo, které se uplatňuje jako ploché šupinky na jemném povrchu

3. jako povrch

4. oxidační, opticky střední až tvrdý výpal

5. jemný, pečlivě upravený, slída na povrchu

6. CRF14, blížící se 212 a 215, Dvakačovice 18, Košumberk 214, Oheb 7, P004, Ra31, Vildštejn 3

\section{5 redukční s písčitým ostřivem}

1. černošedá, šedá, tmavě šedá

2. písčité ostřivo (1-2,5 mm), slída jemně mletá muskovitická v těstě i na povrchu

3. šedý, světle šedý

4. redukční, opticky tvrdý

5. jemný hlazený a leštěný, slída na povrchu, vytáčení

6. CRF15, blízká 214, Dvakačovice 5, Košumberk 215, Lažany 4, Oheb 19, Ra26, Seč 8, Strádov 9 , Vildštejn 4

\section{6 redukční s kožovitým povrchem}

1. tmavě šedá, černošedá a šedá

2. písčité ostřivo (až $1,5 \mathrm{~mm}$ ), slída velmi jemně mletá

3. světle šedý, bělobéžový (lomem a charakteristikou se blíží redukčnímu zboží 217)

4. redukční, opticky tvrdý

5. střední, jakoby kožovitý přetah, ostřivo vystupuje na povrch, vytáčení

6. CRF16, Dvakačovice 24, Košumberk 216, Kovářov 3, P002, Podlažice 14

\section{7 šedé redukční zboží}

1. černá, šedá, šedobéžové, bělošedá, šedobílá, kovově šedá lesklá

2. mikroskopické ostř̌ivo, místy ojedinělý kamínek

3. světle šedá až bělobéžová a krémově bílá

4. redukční, opticky tvrdý

5. jemný, někdy leštěný vodorovně a radiálně, často kovově lesklý, vytáčení

6. CRF17, Bolešov 5, Dvakačovice 4, Hrochův Týnec 8, Jezbořice 5, Košumberk 217, Kovářov 1, Křižanovice 4, Lažany 13, Lhota u Skutče 2, Liboměřice 2, NH4, Oheb 4, P001, Podlažice 7, Ra4, Ro4, Rychmburk 4, Seč 3, TK4, Vildštejn 2, Žumberk 1

\section{8 oxidační zboží s přetaženým krupičkovitým povrchem jemné na dotyk}

1. oranžová, světle hnědá, okrová

2. jemné písčité ostřivo (okolo $0,5 \mathrm{~mm}$ ), slída velmi jemně mletá, dutiny $(0,5-1 \mathrm{~mm})$

3. sendvičový efekt, světlá, tmavé jádro, světlá

4. oxidační, opticky měkký až střední

5. jemný přetažený krupičkovitý povrch, jemné na dotyk

6. CRF18, Dvakačovice 14, Košumberk 218, Lhota u Skutče 3, NH13, Oheb 6, Ra36, Ro14, Seč 6, Vildštejn 6 


\section{9 oxidační zboží se sendvičovým efektem a kožovitým povrchem}

1. béžová, hnědookrová a světle hnědá

2. písčité ostřivo kamínky $(0,5-2 \mathrm{~mm})$, jemně krupičkovité, mírně porézní

3. sendvičový efekt

4. oxidační, sendvičový efekt, opticky tvrdý

5. kožovitý, pečlivě upravený povrch

6. Dvakačovice 15, částečně spadá i do okruhu bílé červeně malované, místy i archaičtější radélko Ra16, Košumberk 219, Křižanovice 3, Lažany 5, NH10, Oheb 24, P003, Podlažice 1, Ro12, Seč 9, Vildštejn 7, Žumberk 16

\section{0 hrubší oxidační zboží}

1. okrová až béžová

2. kamínky $0,5-1 \mathrm{~mm}$

3. okrový

4. oxidační, opticky tvrdý

5. středně hrubý, ostřivo vystupuje na povrch, vytáčení

6. Dvakačovice 20, Jezbořice 6, Košumberk 220, Lažany 7, NH3, Ra9

221

1. oranžová

2. malé kamínky 0,3-0,5 mm, slída

3. světle hnědý, okrový, oranžový

4. oxidační, opticky měkký

5. středně hrubý, ostřivo vystupuje na povrch, obtáčení

6. Košumberk 221, Ra12

\section{2 kachle}

1. světle i tmavě oranžová, cihlově okrová, hnědookrová

2. kamínky $0,5-1 \mathrm{~mm}$

3. světle i tmavě oranžová, cihlově okrová, hnědookrová

4. oxidační, opticky střední

5. hladký

6. Dvakačovice 1, NH1, Oheb 2, P006, Podlažice 16, Ra11, Ro25, Rychmburk 3, Žumberk 8

\section{4 severomoravský výrobní okruh}

1. vně béžové až šedé a tmavě hnědé a hnědošedé, uvnitř šedé, béžové, hnědé a tmavě hnědé až šedohnědé

2. ostřivo 0,5-5 mm, kamínky, póry

3. sendvičový efekt

4. oxidačně redukční, opticky tvrdý

5. hrubý, silně porézní, vytáčení/obtáčení

6. Dvakačovice 19, Košumberk 224, NH8, Oheb 5, Podlažice 8, Ra14, Rychmburk 5, Strádov 2, Vildštejn 1, Žumberk 14 


\section{5 kamenina}

1. hnědá, šedá, žlutá

2. slinutý

3. šedý

4. oxidační, velmi tvrdý

5. pečlivě upravený povrch vně, solná glazura hnědých tónů, uvnitř deformační rýžky

6. Dvakačovice 27, Košumberk 225, Seč 10

\section{6 zboží typu Husova ulice}

1. okrová, světle oranžová; uvnitř hnědočerveně transparentně glazovaný

2. mikroskopické ostřivo, plavené těsto

3. okrová, světle oranžová

4. oxidační, opticky střední až měkký

5. hladký, pečlivě upravený, vytáčení; částečně i oboustranně glazovaný hnědou, hnědočervenou žlutavou, žlutozelenou transparentní glazurou

6. Dvakačovice 11, Jezbořice 8, Košumberk 226, NH5, Oheb 26, Ra8, Ro15, Vildštejn 8, Žumberk 4

\section{7 žlutě a z̆lutozeleně transparentně glazovaná}

1. oranžová, hnědočervená, červená, uvnitř částečně žlutě a žlutooranžově transparentně glazovaná

2. písčité ostřivo (do $1 \mathrm{~mm}$ ), dutinky

3. oranžový, okrový, červený místy i sendvičový efekt

4. oxidační, opticky měkký až střední

5. pečlivě upravený, uvnitř částečně žlutě a žlutooranžově transparentně glazovaná

6. Hrochův Týnec 6, Jezbořice 7, Košumberk 227, Lažany 14, Strádov 11

\section{9 hnědá tvrdá}

1. vně hnědá, uvnitř černošedá

2. mikroskopické ostřivo, dutinky, absence slídy

3. hnědočervený, hnědý

4. tvrdý, oxidačně redukční, vytáčení

5. hladký, pečlivě upravený

6. Dvakačovice 16, Košumberk 229, Křižanovice 5, Liboměřice 3, Oheb 14

\section{0 protoredukční}

1. šedá, šedočerná a černá

2. středně hrubý písek, výrazné procento jemně mleté slídy

3. světle šedá

4. redukční, opticky tvrdý

5. středně hrubý, pečlivě upravený

6. Bolešov 4, Dvakačovice 23, Košumberk 230, Lhota u Skutče 5, Oheb 18, Podlažice 15, Ra27, Stoupec 5

\section{1 oxidační zboží s mikroskopickým ostřivem bez glazury}

1. oranžová, hnědočervená, červená 
2. písčité ostřivo (do $1 \mathrm{~mm}$ ), dutinky

3. oranžový, okrový, červený místy i sendvičový efekt

4. oxidační, opticky měkký až střední

5. pečlivě upravený, vytáčení, modelační rýžky

6. Bolešov 6, Dvakačovice 13, Košumberk 231, Kovářov 5, Křižanovice 2, Lhota u Skutče 6, Oheb 15, P008, Ra32, Ro5, Stoupec 6, Strádov 16

Pozn. Spadá sem i světlá varianta severomoravského výrobního okruhu.

\section{2 světlé šedé slídnaté zboží typu Zbyslavec}

1. světle šedá

2. velmi drobné písčité a slídnaté ostřivo $(1,5-2 \mathrm{~mm})$

3. světle šedý

4. redukční, opticky měkký

5. pečlivě upravený hladký až střední, vytáčení

6. Bolešov 3, Dvakačovice 6, Košumberk 232, Oheb 10, Podlažice 6, Ra34, Ro9, Seč 2

\section{Protosteinzeug}

1. kovově šedá lesklá

2. mikroskopické ostřivo, místy ojedinělý kamínek

3. sendvičový efekt, světle šedá až bělobéžová a krémově bílá

4. redukční se sendvičovým efektem, opticky tvrdý

5. jemný leštěný, kovově lesklý, vytáčení

6. Podlažice 3

\section{6 redukční kachle}

1. šedá až šedohnědá, tmavě šedočerná

2. velmi drobné písčité ostřivo

3. světle šedý

4. redukční, opticky velmi tvrdý

5. pečlivě upravený, vytáčení

6. Dvakačovice 12, Oheb 1

\section{Novověk 3-}

\section{2 glazovaná oxidační bez nástřepí II}

1. bělobéžová, uvnitř částečně transparentní glazura žlutá, nazelenalá, nahnědlá

2. jemné plavené těsto, mikroskopické ostřivo

3. bílý, bělobéžový

4. oxidační, opticky střední

5. jemný pečlivě upravený povrch, hladký, modelační rýžky

6. Dvakačovice 9, Košumberk 312, Křižanovice 7, Lhota u Skutče 10, Liboměřice 4, Ra28, Ro7, Rychmburk 8, Seč 4, TK5, Žumberk 3, Žumberk 10, Žumberk 11, Žumberk 15

\section{0 bělobéžová bez glazury}

1. bělobéžová

2. jemné plavené těsto, mikroskopické ostřivo 
3. bílý, bělobéžový

4. oxidační, opticky střední

5. jemný pečlivě upravený povrch, hladký, modelační rýžky

6. technologicky jako 312 jen bez glazury, Dvakačovice 17, Košumberk 320, Kovářov 7, Křižanovice 8 , Oheb 20, Podlažice 4, Ro10

\section{Prameny a literatura}

BALOGHOVÁ, R., 2010: Archeozoologie tř́i vrcholně středověkých parcel v Chrudimi - Hradební ulici. Nepublikovaná diplomová práce, Př́rodovědecká fakulta Jihočeské univerzity v Českých Budějovicích.

BARTOŠOVÁ, L., 2009: Paleoparazitologická analýza organických sedimentů archeologického naleziště v Chrudimi. Nepublikovaná bakalářská práce, Př́rodovědecká fakulta, Jihočeská univerzita v Českých Budějovicích.

BARTOŠOVÁ, L. a kol., 2011: Bartošová, L.-Dittrich, O.-Beneš, J.-Frolík, J.-Musil, J., Paleoparasitological Findings in Medieval and Early Modern Archaeological Deposits from Hradební Street, Chrudim, Czech republic, IANSA 11/1, 39-50.

CEJPOVÁ, M., 2008: Zbyslavec, okr. Chrudim, Výzkumy v Čechách 2005, 312.

CYMBALAK, T.-MATĚJKOVÁ, K., 2012: Zpracování nálezů ze dvou odpadních jímek a úskalí jejich interpretace - Analysis from two cesspits and problems with thein interpretation, Staletá Praha 28, 41-76.

ČECHURA, J., 2008: Hry v životě středověkého člověka. Pokus o rekonstrukci způsobů tráveni volného času ve stř̌edověku na př́kladu archeologických nálezů pozůstatků deskových her - Games and Toys in the Medieval Everyday Life. An attempt to Restore the Ways of Spending the Free Time in the Middle Ages on the Example of Archaelogical Finds of Board Games. Diplomová práce, Ústav pro pravěk a ranou dobu dějinnou, Filozofická fakulta, Univerita Karlova, Praha.

ČERNÁ, E., 1996: Středověké sklo z Ústí n. L. - Hradiště. Ústecké muzejní sešity. Ústí nad Labem.

- 1995: Nálezy skel ze středověkého Mostu - Mittelalterliche Gläser aus Most. In: Archeologické výzkumy v severozápadních Čechách v letech 1983-1992 (Blažek, J.-Meduna, P., edd.), 239-262. Most.

- 2005: Soubory skel z Chrudimi, Filištínské ulice, Chrudimský vlastivědný sborník 9, 3-35.

DÁŇOVÁ, H.-PRAŽÁKOVÁ, M., 2019: Uprostřed Koruny české. Gotické a renesanční umění východních Čech 1250-1550. Průvodce výstavou. Hradec Králové.

DOLEŽEL, J., 2008: Středověká miskovitá (lotová) závaží v českých a moravských nálezech - Medieval cup nested weights in Bohemian and Moravian findings, PV 49, 183-215.

FILIPOVÁ, N., 2017: Římské stolní a deskové hry v archeologickém kontextu - Roman Board and Table Games in Archaeological Context. Bakalářská práce, Ústav pro klasickou archeologii, Filozofická fakulta, Univerzita Karlova, Praha.

FLORIÁN, Č., s. d.: Topografie Chrudimi I. Rukopis. Státní Okresní archiv v Chrudimi. Fond Pozůstalost Vincence Floriána, kart. 1, inv. č. 16.

FROLÍK, J., 1982: Archeologické nálezy a minulost Skutečska. Skuteč.

- 1984: Archeologické nálezy. Chrudimsko /k-t/. Chrudim.

- 2019: Kostel sv. Václava v Lažanech a počátky středověkého osídlení Skutečska. Díl II. Analýza - The Church of St. Wenceslas in Lažany and the Beginning of the Medieval Settlement of the Land of Skuteč. Part II. Analysis. Projekt ABG 3/2. Praha.

FROLÍK, J.-KOZÁKOVÁ, R.-MUSIL, J., 2018: Jímka 938 z Chrudimi Hradební ulice. Pokus o určení statutu jejího majitele - Abwassergrube 938 in Chrudim - Hradební Straße. Verduch einer Statusbestimmung ihres Besitzers, AH 43, 455-489.

FROLÍK, J.-MÁCALOVÁ, M.-STRÁNSKÁ, P., 2016: Kostel sv. Václava v Jezbořicích (okr. Pardubice) a počátky pohřbívání u něho - St. Wenceslas Church of Jezbořice (District Pardubice) and Origin of Burials, Východočeský sborník historický 30, 5-97.

FROLÍK, J.-MUSIL, J., 2007: Záchranné archeologické výzkumy v Chrudimi v roce 2006 - Archäologische Rettungsgrabungen im Chrudim im J. 2006. In: Archeologické výzkumy v Čechách 2006. Sborník 
referátů z informačního kolokvia. Zprávy České archeologické společnosti - Supplément 68 (Sklenár̆, K., ed.), 46-48. Praha.

- 2010: Záchranný archeologický výzkum v Hradební ulici v Chrudimi v roce 2006, Chrudimský vlastivědný sborník 14, 3-28.

- 2014: Nejstarší zástavba Chrudimi po založení města ve 2. polovině 13. století - Die älteste Bebauung in Chrudim nach der Stadtgründung in der 2. Hälfte des 13. Jahrhunderts, Forum urbes medii aevi VIII, $46-67$.

FROLÍK, J.-MUSIL, J.-SIGL, J., s. d.: Manuál technologických skupin středověké a novověké keramiky na Chrudimsku. Rukopis uložený na archeologickém pracovišti Regionálního muzea v Chrudimi.

FROLÍK, J.-SIGL, J., 1990: Soubor pozdněstředověké keramiky z Chrudimi - Husovy ulice - A group of late Mediaeval pottery from the town of Chrudim (Husova Street), Studies in Post-Medieval Archaeology 1, 269-284.

- 1995: Chrudimsko v raném středověku - Chrudim Region (East Bohemia) in the Early Middle Ages. Development of settlement and related structural changes - Das Chrudimer Land im Frühmittelalter. Die Entwicklung der Besiedlung und seine strukturellen Probleme. Hradec Králové.

- 1997: Předstihový archeologický výzkum v Chrudimi - Filištínské ulici na staveništi nové budovy okresního archivu v roce 1996 - Precedence archaeological excavations at Chrudim-Filištínská street, at the site of a new District archive building in 1996, ZMHK 23, 86-95.

- 1998: Chrudim v pravěku a středověku. Obrazy každodenního života. Chrudim - Chrudim in Prehistory and the Middle Ages. Picture sof Everyday Life - Chrudim in der Urgeschichte und im Mittelalter. Bilder aus dem Altagsleben. Chrudim.

- 1999: Nálezová zpráva o záchranném archeologickém výzkumu na lokalitě Chrudim - Filištínská ulice čp. 37/I-40/I. Svazek 4 - Sumarizace nálezů - čp. 37/I, sondy A, B, čj. 819/99, ulož. v Archivu nálezových zpráv ARÚ Praha.

FROLÍK, J.-STRÁNSKÁ, P.-ŠVÉDOVÁ, J., 2018: Hrochův Týnec, počátky zdejšího kostela sv. Martina a feudálního sídla - Hrochův Týnec, the beginnings of the local Church of St. Martin and of a feudal residence, ASČ 22, 971-1004.

FRÝDA, F., 2007: Nálezy renesančního skla z Plzně. In: Historické sklo 4. Sborník pro dějiny skla, 33-65. Čelákovice.

GABRIEL, F.-SMETANA, J., 1983: K vývoji výrobních okruhů červeně malované keramiky v severních Čechách - Zur Entwicklung der Produktionsbereiche rotbemalter Keramik in Nordböhmen, AH 8, 119-138.

GOŠ, V., 2007: Loštice: město středověkých hrnčiřrů. Opava.

HAGGRÉN, G.-SEDLÁČKOVÁ, H., 2007: Ribbed beakers with applied glass threads in Europe - Číšky $\mathrm{s}$ taženými kapkami v Evropě, PA XCVIII, 185-250.

HAIS, R. a kolektiv, 2010: Sklářské názvosloví aneb co je co ve sklářství. Česká sklářská společnost Teplice. HEJDOVÁ, D., 1967: Příspěvek k typové chronologii středověkého skla v Čechách, ČNM CXXXVI, 168-176.

HEJDOVÁ, D.-NECHVÁTAL, B., 1967: Studie o středověkém skle v Čechách (Soubor z Plzně, Solní ul.) Studie ueber das Mittelalterliche Glas in Boehmen (Fundkomplex aus Plzeň, Solní ul.), PA LVIII, 433-498.

HEJDOVÁ, D. a kol., 1983: Hejdová, D.-Frýda, F.-Šebesta, P.-Černá, E., Středověké sklo v Čechách - Mittelalterliches Glas in Böhmen, AH 8, 243-265.

HIMMELOVÁ, Z., 1991: Př́íspěvek k typologii středověkého dutého skla - Beitrag zur Typologie des mittelalterlichen hohlen Glases. In: Historické sklo 1. Sborník pro dějiny skla. Čelákovice: Sklářská odborná sekce pro dějiny skla při České archeologické společnosti, 13-16. Čelákovice.

HOCH, A., ed., 2020: Svět středověkých her. Katalog výstavy. Jihlava - Plzeň.

CHVÁTAL, M.-ROUS, P.-VOKÁČ, M.-ZIMOLA, D., 2013: Střepy nádob z raně novověkých hrnčiřských dílen ledečských hrnčířu - Fragments of vessel from Early Modern-Age workshops of the potters in Ledeč, Výzkumy na Vysočině 4, 184-200.

JANOVÍČKOVÁ, M.-SEDLÁČKOVÁ, H., 2008: Obchod se sklem ve střední Evropě ve 13. a 14. století na př́íkladu konvic typu „Mečová“ a stolních láhví typu „Norimberk“. In: Odorik z Pordenone: z Benátek do 
Pekingu a zpět. Setkávání na cestách Starého světa ve 13.-14. století. Sborník příspěvků z mezinárodní konference. Colloquia mediaevalia Pragensia 10, 257-278. Praha.

KNÁPEK, R.-ŠEDO, O., 2018: Mocní a jejich hry: hrací kostky v rukách př́íslušníků elit doby římské Mighty Ones and their Games: Dice in the hands of Roman peiod elite members, Živá archeologie REA 19, 25-34.

KODÝDKOVÁ, K., 2009: Analýza rostlinných makrozbytků ze středověké odpadní jímky v Chrudimi. Nepublikovaná bakalářská práce, Př́írodovědecká fakulta, Jihočeska univerzita v Českých Budějovicích.

KRAJÍC, R., 2003: Sezimovo Ústí. Archeologie středověkého města 3. Kovárna v Sezimově Ústí a analýza výrobků ze železa. Díl I. - Die Schmiede in Sezimovo Ústí und Analyse der Produkt aus Eisen. Sezimovo Ústí - Archäologie der mittelalterlichen Untertanestadt 3. Praha - Sezimovo Ústí - Tábor.

LACINA, M.-MUSIL, J., v tisku: Aktuální stav poznání hradu Rabštejnka (okr. Chrudim) a jeho hmotné kultury, CB.

LEHEČKOVÁ, E., 1975: Nové nálezy středověkého skla z Kutné Hory - Neue mittelalterliche Glasfunde aus Kutná Hora, PA LXVI, 450-485.

MALINA, O.-MUSIL, J.-NETOLICKÝ, P., 2019: Změny sídlištních struktur v okolí Ronova nad Doubravou - Veränderungen der Siedlungsstruktur im Umland von Ronov an der Doubrava, AH 44, 855-885.

MUSIL, J., 2009: An assemblage of late Middle Age and Early Modern period ceramics from Rabštejnek Castle in the cadastral territory of Smrkový Týnec in the district of Chrudim, Studies in Post-Medieval Archaeology 3, 45-64.

- 2011: Nové středověké a raně novověké nálezy z Trhové Kamenice (okr. Chrudim, Pardubický kraj) - New Medieval and Early-Modern Discoveries in Trhová Kamenice (Chrudim District, Pardubice Region), Východočeský sborník historický 19, 59-104.

- 2011a: Příspěvek archeologie k dějinám Trhové Kamenice, okr. Chrudim - Der Beitrag von der archäologie zur Geschichte von Trhová Kamenice, Bez. Chrudim, ASČ 15, 969-988.

- 2013: Katalog archeologických nálezů z hradu Rabštejnka - Archaeological Finds from Rabštejněk Castle. Sbírky regionálního muzea v Chrudimi 7/II. Chrudim.

- 2014: Soubor keramiky z velitelského stanoviště pod hradem Lichnicí (k. ú. Podhradí v Železných horách, okr. Chrudim) - A ceramic assemblage from the command post under Lichnice Castle (cadastral area of Podhradí v Železných horách, Chrudim District), AVČ 5, 87-111.

- 2016: Př́ispěvek k poznání hmotné kultury hradu Strádova (k. ú. Ochoz u Nasavrk, okr. Chrudim) - Ein Beitrag zur Kenntnis der matereillen Kultur der Burg Strádov, AVČ 8, 54-87.

- 2017: Počátky Lhoty u Skutče (archeologie žijící vesnice), Chrudimské vlastivědné listy 26, č. 5, $13-17$.

- 2018: Novověká jímka na hradě Košumberku, CB 18, 77-99.

- 2019: Zaniklá středověká vesnice pod Sečskou přehradou (katastrální území Seč a Hoješín, okres Chrudim) aneb Ústupky roku 1315?, Chrudimský vlastivědný sborník 23, 119-150.

MUSIL, J.-NETOLICKÝ, P., 2012: Zaniklá středověká a raně novověká ves Bolešov v k. ú. Spačice, okres Chrudim, Pardubický kraj - The Perished and Early-Modern-Age Village of Bolešov in the Cadastral Territory of Spačice, District of Chrudim, the Pardubice Region, Východočeský sborník historický 22, $73-114$.

- 2014: Tvrziště Stoupec a jeho hospodářské zázemí. Výsledky povrchového průzkumu na k. ú. Březinka u Hoštalovic (okr. Chrudim) - Fortress Stoupec and it's economic accessories. Results of survey on the Březinka u Hoštalovic cadaster (Chrudim District), AVČ 5, 148-180.

- 2016: Nové archeologické nálezy z tzv. bojanovského újezdu (Železné hory, okres Chrudim) - New archaeological finds from so-called the Bojanov district (Železné hory, district of Chrudim, E Bohemia), Praehistorica XXXIII, č. 1-2, 275-290.

NECHVÁTAL, B., 1967: Středověká keramika z Ledče nad Sázavou - Die mittelalterliche Keramik aus Ledeč nad Sázavou, AR XIX, 542-543.

NEKUDA, V.-REICHERTOVÁ, K., 1968: Středověká keramika v Čechách a na Moravě - Mittelalterliche Keramik in Böhmen und Mähren. Brno.

NOVÁK, M., 2010: Pravěké osídlení Chrudimi - Hradební ulice, Chrudimský vlastivědný sborník 14, 29 -67. PAVLŮ, I., 1982: K počátkům Čáslavě. I. Katalog - Archeologické nálezy při městských hradbách, Praehistorica X - Varia archaeologica 3, 75-160. 
- 1991: K počátkům Čáslavě. II. Zhodnocení archeologických dat, Praehistorica XVIII - Varia archaeologica 5, 119-137.

SEDLÁČKOVÁ, H., 2001: Gotické sklo na střední a severní Moravě v archeologických nálezech - Gotisches Glas in den archäologischen Funden aus Mittel- und Nordmähren, Archaeologia historica 26/01, 411-428.

- 2001a: Soubor renesančního skla z areálu novokřtěnského dvora ve Strachotíně (okr. Břeclav), JM 37, $43-68$.

SEDLÁČKOVÁ, H., ed., 2019: Glass in Brno and Moravia ca. 1200-1550. Vol. I. Assessment of finds. Brno. - 2019a: Glass in Brno and Moravia ca. 1200-1550. Vol. II. Catalogue of glass. Brno.

ŠLANCAROVÁ, V., 2018: Středověký šperk. Archeologické nálezy z jižní Moravy. Katalog nálezů. Brno.

ŠVECOVÁ, R., 2001: Nálezy astragalov na Pohansku při Breclavi - Findings of the Astragals in Pohansko near Břeclav, SPFFBU M 6, 149-165.

TOMÁŠEK, M., 1995: Archeologický výzkum hradebního pásma v Č́slavi v roce 1993 - Die archäologische Ausgrabung der Befestigungszone in Čáslav in J. 1993, AR XLVII, 444-454.

VAŘEKA, P., 1998: Proměny keramické produkce vrcholného a pozdního středověku v Čechách - The erratic character of ceramic production in High and Later Middle Age in Bohemia, AR L, 123-137.

ŽĎÁRSKÁ, A., 2014: Středověké sklo z Prahy. Archeologické prameny k dějinám Prahy. Svazek 7. Praha.

\section{Zusammenfassung}

\section{Zwischen Glas und Keramik. Die mittelalterliche Abwassergrube 962 aus Chrudim - Hradební-Straße}

Im Jahr 2006 erfolgte im historischen Kern der ostböhmischen Stadt Chrudim die bisher größte archäologische Rettungsgrabung, und zwar in der Hradební-Straße auf den Parzellen der untergegangenen Häuser mit der Konskriptionsnummer 14/I und 15/I sowie im ursprünglich zu Konskriptionsnummer 10/I gehörenden Garten (Abb. 1 - Frolík-Musil 2007; 2010). Auf der untersuchten Fläche kam dies durch Vermessung von drei an der Ostseite an die Straße (heute Hradební-Str.) angrenzenden Stadtparzellen zum Ausdruck. Deutlicher Bestandteil des Befundbildes sind Abwassergruben und Abfallgruben (Abb. 1). Chronologisch decken sie den Zeitraum zwischen der Wende des 13. und 14. Jahrhunderts bis zum achtzehnten Jahrhundert ab. Nur eine Abwassergrube hängt mit dem Haus der Konskriptionsnummer 15/I zusammen (Abwassergrube 962). Alle Abwasser- und Abfallgruben wurden nach natürlichen Schichten untersucht, was es erlaubte, die Art und Weise ihrer Verfüllung detailliert zu beobachten. In den Abwassergruben befand sich ursprünglich eine weiche unkonsolidierte Verfüllung, die nach und nach absackte, sodass sie eine charakteristische Schichtung mit Ablagerungen bildete, deren Ränder entlang den Wänden der Abwassergrube nach oben hinausliefen (der Schnitt durch die Ablagerung gleicht dem Buchstaben U). Die weiche Verfüllung machte es zweifellos auch möglich, zumindest am Anfang, dass schwerere Gegenstände in ältere Ablagerungen durchsackten. Für gewöhnlich wurde der obere Teil der Abwassergrubenverfüllung durch eine viel jüngere Schichtenfolge unterschiedlichen Charakters gebildet, häufig mit Funden aus dem 18. bis 19. Jahrhundert (z. B. Abwassergrube 938). Bei einigen Abwassergruben gelang es zu belegen, dass über ihnen offenbar ein leichterer Holzbau gestanden hatte (Abort?, z.B. Abwassergrube 932 - Frolík-Kozáková-Musil 2018). Die älteste Erwähnung des Eckhauses der Konskriptionsnummer 15/I finden wir zum Jahr 1601, als der berühmte Chrudimer Maler Matouš Radouš das Haus an einen Schankwirt Martin verkauft hat. Sein Schicksal können wir bis zum Jahr 1637 verfolgen. Anschließend wurde es zerstört, da die Stadt im Jahr 1711 die „leere Stelle“ für einen Neubau verkaufte. Das Haus, das dort bis in die neunziger Jahre des vergangenen Jahrhunderts stand, wurde im 19. Jahrhunderts erbaut und ersetzte einen nach 1711 entstandenen Bau (Übersicht der schriftlichen Nachrichten nach Florián, undatiert). 
Abwassergrube 962 befand sich isoliert in der nordwestlichen Ecke von Quadrat G6. Sie war mit Bruchsteinpläner auf Lehm ausgemauert (Außendurchmesser 1,7 × 1,8 m, Innendurchmesser $1,2 \times 0,95 \mathrm{~m}$, die Tiefe erreichte 2,6 m). Die Verfüllung setzte sich aus insgesamt 20 verschieden starken Ablagerungen zusammen (G6/125 bis G6/144), die man in drei Teile mit ähnlichen Eigenschaften unterteilen kann (Abb. 2). Der untere Teil zeichnet sich im Umfang der Ablagerungen G6/135 bis G6/144 durch Vorkommen von Holz- und Holzkohlebruchstücken aus (35 bis $45 \%$ Ablagerungen G6/136 und G6/142). Die Gesamtstärke dieses Teils der Schichtung beträgt 1,05 m. Höher tut sich der Charakter der Ablagerungen ändern, das Vorkommen von Plänersteinen nimmt zu (20 \%-30 \%; Ablagerungen G6/134, G6/133, G6/130, G6/128 und G6/126), was als Beleg für Steinkonstruktionen in der Umgebung angesehen werden kann (Abb. 3). Eine weitere Änderung der Höhe von Ablagerung G6/130 signalisiert das Vorkommen von Ziegelsteinfragmenten (G6/130 und G6/125). Die Gesamtstärke des oberen Teils der Schichtenfolge beträgt 0,95 $\mathrm{m}$ bei den Schichten, in denen nur Plänersteine vorkommen (G6/134 bis G6/131), und 0,7 m bei den Schichten, in denen bereits Ziegelsteinfragmente auftauchen (G6/130 bis G6/125). Die Verfüllung der Abwassergrube belegt aufgrund des veränderten Charakters der Ablagerungen mindestens zwei Verfüllungsetappen. Von den Überresten her älter sind die Schichten bis zur Höhe von Ablagerung G6/135, höher gelegene hängen mit der jüngeren Etappe der Abwassergrubennutzung zusammen, und zwar zweifellos nach einer teilweisen Aushebung der älteren Verfüllung. Ein eventueller kleiner Unterschied im Charakter der Schichten ab Ablagerung G6/130 und ein möglicher Beleg für eine dritte Etappe kann lediglich durch eine Analyse der Funde nachgewiesen werden.

Insgesamt wurden 1273 Keramikbruchstücke, 56 ganze Gefäße und ihre Torsi mit einem Gesamtgewicht von 32259 g ausgewertet. Die Keramik kann aufgrund ihrer makroskopisch erfassbaren Eigenschaften in 32 technologiche Keramikgrundklassen (ferner KK) untergliedert werden, die auch eine chronologische Bedeutung haben. Außer einer lokalen Produktion tauchen auch Importe aus deutscher Umgebung auf (qualitativ hochwertige graue metallglänzende Keramik mit weißem Bruch - KK 235), die durch einen Grapentorso (Abb. 6:4) und mehrere Bruchstücke vertreten waren, die wahrscheinlich von einem rädchenverzierten und mit einem wulstartigen Spiraldekor versehenen Krug stammen. In Fülle vertreten ist offenbar von lokalen Werkstätten stammende Ware, die wohl im Umkreis von Čáslav, Chotěboř oder Ledeč nad Sázavou hergestellt wurde. Sie kommt im breiteren Gebiet zwischen Ronov nad Doubravou und Chrudim vor (KK 212 und 232). Die Keramikklassen KK 218-221, 229 und 230 entsprechen der Verteilung der in Vergangenheit von P. Vařeka (1998) abgegrenzten Vertriebszonen. Laut ihm wird der Norden unseres Gebietes von fest gebrannter Oxidationskeramik eingenommen, der Süden von grauer Reduktionskeramik, und dazwischen liegt ein Streifen mit grober, mittelfest gebrannter Oxidationskeramik. In dieser Zone sollte noch Čáslav und der angrenzende östliche Teil Mittelböhmens vorkommen. Die Zeit ab Ende des 14. Jahrhunderts bedeutet in der Chrudimer Sachkultur einen massiven Zustrom dunkler Reduktionsware aus verschiedenen Produktionsgebieten (Čáslav, Chotěboř, Ledeč nad Sázavou). In unserer Kollektion tauchen insgesamt vier technologische Keramikklassen auf (KK 214-217), die sich in Brandqualität, dem verwendeten Magerungsmittel und in der Oberflächenbehandlung voneinander unterscheiden. Nur allgemein in die Zeit des 14.-15. Jahrhunderts können wir Funde aus dem Umkreis von heller bis weißer Keramik mit roter Bemalung einordnen (KK 213). Nur vereinzelt ist das Vorkommen von Keramik des nordmährischen Produktionsumkreises belegt (KK 224). Nur allgemein in die Zeit des 14.-15. Jahrhunderts können wir ein kleines atypisches Steinzeugfragment (KK 225) und teilweise gelb und gelb-orange transparent glasierte Oxidationskeramikware (KK 227) einordnen. Bei der beginnenden frühmittelalterlichen Keramikproduktion vom Ende des 15. und der ersten Hälfte des 16. Jahrhunderts handelt es sich um eine spezifische braunrot transparent glasierte Ware vom Typ der Husova-Straße (KK 226). In den Verlauf des 15. bis zum Beginn des 16. Jahrhunderts können wir auch dir relativ zahlreich vertretene feine unglasierte Oxidationsware (KK 231) einordnen. Die jüngste Komponente der Kollektion stellt glasierte (KK 312) und unglasierte neuzeitliche Ware (KK 320) dar, die den Zeitraum des 17. und 18. Jahrhunderts 
umfasst. Eine eigenwillige Stellung in der Kollektion repräsentieren Kachelfragmente (Abb. 7), die zwei technologischen Keramikklassen angehören (KK 222 und KK 236). Es sind sowohl Blattkacheln, bauchige Gefäßkacheln und Gefäßkacheln mit rechtwinkliger Mündung vertreten. Wenn man die Ergebnisse dieser Analyse auf die stratigraphische Situation überträgt, zeichnen sich deutlich zwei klar voneinander getrennte Horizonte ab (Abb. 2). Den ersten, jüngeren stellen die Ablagerungen G6/125 bis G6/138 (Abb. 4) dar. Aus Sicht des Materials stellen die Verfüllungen eine mannigfaltige Mischung aus Keramik aus dem frühen Mittelalter bis zu neuzeitlicher Keramik dar. Der zweite, ältere Horizont von Ablagerung G6/139 bis zum Boden der Abwassergrube ist chronologisch viel geschlossener, er enthält keine jüngeren Funde, frühmittelalterliche Funde tauchen nur in geringem Maße auf (Abb. 5, 6, 7:8). Sehr gut zu beobachten ist die Bewegung von Gefäßfragmenten in offenbar konsistenten Fäkalverfüllungen in Höhe der Ablagerungen G6/139 bis G6/143.

Die Abfallgrube 962 im Quadrat G6 enthielt neben einer Fülle von Küchenkeramik auch zahlreiche Fragmente von Glasgefäßen aus der Zeit des 14. bis 16. Jahrhunderts. Das gewonnene Material läßt sich aufgrund der typologisch-chronologischen Auswertung in zwei Horizonte unterteilen. Den ersten Horizont repräsentiert gotisches Glas in den Ablagerungen G6/135 bis G6/144, also Glas, das im Laufe des 14. und 15. Jahrhundert verwendet wurde. Dort am meisten vertreten sind für diesen Zeitraum charakteristische Becher tschechischen Typs und Becher oder Trinkbecher mit gezogenen Tropfen. Beide Formen zählten im Mittelalter zur gängigen Glasproduktion und wurden relativ zahlreich in bürgerlichen Haushalten des 14. bis 15. Jahrhunderts benutzt (Abb. 8:2-7, 9, 10, 12, 13). Neben Getränkegläsern stammt eine mit glatten Fäden verzierte Flasche aus diesen Schichten (Abb. 9:3-4). Zum zweiten Horizont zählt Glas aus den Ablagerungen in der oberen Hälfte der Abwassergrube - im Bereich der Ablagerungen G6/134 bis G6/126, die sowohl mittelalterliches, als auch frühneuzeitliches Glas enthielten. Das mittelalterliche Glas besteht aus Bechern und Trinkbechern mit gezogenen Tropfen und aus Bechern tschechischen Typs (Abb. 8:1, 8, 11, 14). Ein unikater Fund ist ein Flaschenhals des Typs Nürnberg oder eine Kanne des Typs Mečová, die zu für höhere Gesellschaftsschichten erschwinglichem Luxusglas zählten (Abb. 9:1). Renaissanceglas ist vor allem als Pokalfragmente mit halbeiförmiger oder spindelförmiger Kuppa und als Fragmente von zylinderförmigen Bechern oder Trinkbechern vertreten (Abb. 9:2, 8, 9). Einige dieser Gefäße sind mit einem optischen Dekor verziert (vor allem mit vertikalen Rippen oder mit Linsen), das durch Ausblasen des Glaskolbens in Metall- oder Holzformen entstand (Abb. 9:10-12). Aus diesem gemischten Horizont wurden auch Fensterglasfragmente gewonnen - Butzenscheiben und dreieckige Füllungen (Abb. 9:5-7). Insgesamt stammen aus der Abfallgrube mindestens zehn Glasgefäße aus der Zeit des Hoch- und Spätmittelalters. Schätzungsweise befanden sich dort mindestens sieben bis acht Renaissancegefäße und einige Fensterscheiben. Die Glasfunde aus Abfallgrube 962 entsprechen der Ausstattung gängiger Bürgerhaushalte für die Zeit des Mittelalters.

Aus der Verfüllung von Abwassergrube 962 wurde auch eine kleine Kollektion an Metallfunden gehoben, und zwar aus Eisen und Bronze. Der überwiegende Teil der Eisengegenstände sind Nägel (37 Stück - Abb. 10/1-20; Abb. 11:1, 7, 8, 10-12, 14, 17-23) und unbestimmbare amorphe Bruchstücke (3 Stücke - Abb. 11:2, 3, 13). Der größte Gegenstand aus dem älteren Teil der Verfüllung ist ein Sperrfedervorhängeschloss aus Bronze (Abb. 10:21). Zur Gruppe der Metallfunde zählt auch eine kleine quadratische Bronzeschnalle (2 g), die wohl zur Befestigung von Sporen am Schuhwerk diente (Abb. 11:5). Ein interessanter Gegenstand ist die kleine Fläche eines Löffels mit tordiertem, von einer Öse abgeschlossenem Griff (Abb. 11:9). Ein wichtiger Gegenstand ist auch das Bronzelotgewicht aus Ablagerung G6/131 (Abb. 12:1), das in das fortgeschrittene 13.-15. Jahrhundert datiert werden kann. Der dritte, stratigraphisch jüngste Teil der Verfüllung (Ablagerungen G6/130 bis G6/125) brachte eine massive ovale Schnalle mit Dorn (22 g - Abb. 11/6). Es handelt sich dabei um einen gängigen Schnallentyp in Form eines D, das für Gürtel, aber auch für Pferdegeschirr verwendet worden sein konnte. Vereinzelt vertreten ist auch Bein, und zwar als Spielstein - einem Astragal mit einem unregelmäßigen plankonvexen 
Geschöpf im Mittelteil (Abb. 12/2) aus dem mittleren Teil der Schichtenfolge. Es handelt sich dabei um einen chronologisch unsensiblen Gegenstand.

Auf dem kleinen Hof der untergegangenen Konskriptionsnummer 15/I wurde die einzig vorhandene Abwassergrube 962 untersucht. Die Analyse der Funde deutet darauf hin, dass die Grube im 14. Jahrhundert in der unteren Hälfte (bis zur Höhe von Ablagerung G6/135) verfüllt wurde. Anschließend kam es offenbar zu einer teilweisen Entnahme des Inhalts und zu einer neuen Verfüllung, und zwar im 16. Jahrhundert. Bei dieser Gelegenheit entstand eine Schichtenfolge mit einer Vermischung des Inhalts mit Funden aus dem 14.-16. Jahrhunderts, die mindestens den Umfang der Ablagerungen G6/131-G6/134 für Glas und G6/131-G6/139 für Keramik umfasst. Der Fundkomplex stellt ein gängiges mittelalterliches Sortiment mit nur einem minimalen Vorkommen von seltenen oder luxuriösen Gegenständen dar (Flasche des Typs „Nürnberg“). Sie geben auch keine Hinweise auf das Gewerbe des Parzellenbesitzers, es ist jedoch möglich, dass er an Handelstransaktionen beteiligt war (Lotgewicht). Das Vorhandensein von nur einer Abwassergrube wirft die Frage auf, wo man den im Haushalt von Konskriptionsnummer 15/I entstandenen Abfall entsorgt hat. Die Fundsituation erlaubt es nicht, das Vorhandensein von weiteren Abwassergruben anzunehmen. Als mehr oder weniger einzige Möglichkeit erscheint eine periodisch erfolgte Leerung der Grube, und zwar in der ältesten Periode (vor dem 14. Jahrhundert und in der Zeit des 15./16. Jahrhunderts). Die zwei erhalten gebliebenen Etappen der Verfüllung können wir als eine zufällig bewahrte Probe eines ursprünglich umfangreicheren Inhalts ansehen.

Die vorliegende Arbeit wurde von der Förderagentur der Tschechischen Republik, Nr. GA 1905677S „Glas in den böhmischen Ländern von der Gotik bis zum Barock gemäß den in Chrudim und Brno gemachten Funden. Die Bedeutung der regionalen Produktion im europäischen Kontext" gefördert.

PhDr. Jan Frolík, CSc., Univerzita Pardubice, Studentská 95, 53210 Pardubice, Česká republika, frolikjano@gmail.com

Mgr. Romana Kozáková, Národní muzeum, Ústřední depozitář II, Prokopa Holého 78, 41155 Terezín, Česká republika,romana_kozakova@nm.cz

PhDr. Jan Musil, Regionální muzeum v Chrudimi, Široká 86, 53701 Chrudim, Česká republika, musil@muzeumcr.cz

Mgr. Kateřina Vad'urová, Archaia Brno z. s., Bezručova 15, 60200 Brno, Česká republika, katkabreckova@seznam.cz 
